\title{
Debreczeni Attila Kiindulópontok és kontextusok Fazekas Mihály életművének újraértelmezéséhez
}

Fazekas Mihály életműve az utóbbi több mint fél évszázadban alapvetően a Julow Viktor által kialakított értelmezés keretei között áll elöttünk. ${ }^{1}$ A fennmaradt szövegkorpusznak az 1955-ös kritikai kiadásban ${ }^{2}$ megszületett életrajzi-kronológiai alapú textológiai konstrukciója nemcsak az azóta készült népszerű kiadásokat, de Julow Viktor Fazekas-pályaképét is döntő mértékben meghatározta. Bécsy Ágnes véleménye szerint Julow Viktornak az így megalapozott 1982-es monográfiájával „sikerült úgy kimerítenie tárgyát és a tudós érdeklődést, hogy a legutóbbi időkig nem mutatkozott elszánás koncepciózus dialógusba ereszkedni vele". ${ }^{3}$ Bécsy Ágnes e sorokat 2002-ben írta, s teljes Fazekas-portrét mindössze egyet tudott említeni az addigi szakirodalomból, Bíró Ferenc 1994-es korszakmonográfiájának fejezetét, ${ }^{4}$ amely eszmetörténeti ihletettségü értelmezést nyújtva helyezte új megvilágításba a Fazekast jellemző sajátos identitásképletet. Az azóta eltelt időszak magányos verselemzése ${ }^{5}$ mellett leginkább a Lúdas Matyi ${ }^{6}$

\footnotetext{
* A Debreceni Egyetem Magyar Irodalom- és Kultúratudományi Intézetének Régi és Klasszikus Magyar Irodalmi doktori mühelyei összevont vitaülésen vitatták meg e dolgozat első változatát, az elhangzott véleményeket, javaslatokat, melyek érdemben hozzájárultak a végső változat kialakításához, minden közreműködőnek nagyon köszönöm, a koncepciót leginkább formáló néhány felvetésre a későbbiekben külön is utalok majd. Ugyancsak itt köszönöm meg Szilágyi Márton megjegyzéseit, melyeket a műhelyvita utáni változathoz füzött, valamint, hogy rendelkezésemre bocsátotta a Lúdas Matyiról korábban publikált tanulmányának a jelen dolgozattal párhuzamosan újraírt változatát.

${ }^{1}$ Julow Viktor, Fazekas Mihály, Bp., Szépirodalmi, 1982. (A kritikai kiadással párhuzamosan készült 1955-ös első kiadás jelentősen átdolgozott és bővített változata.) A monográfiára csak egyetértőleg hivatkozunk, az eltérő vélemények tételes dokumentálása nem látszik szükségesnek egy újraértelmezésre törekvő dolgozatban.

${ }^{2}$ FAZEKas Mihály Összes Müvei, I-II. kötet, s. a. r. Julow Viktor, KéRy László, Bp., Akadémiai, 1955. (a továbbiakban: FMÖM)

${ }^{3}$ BÉCsy Ágnes, Egy jó költő a neoklasszicizmus korának magyar irodalmából: Fazekas Mihály = Pillanatkép a hazai irodalomtudományról, szerk. Kenyeres Zoltán, Gintui Tibor, Bp., Anonymus, 2002, 8. E szöveg a Liget címü folyóiratban Költők „, a titok szent kárpitja” körül. A neoklasszicizmus magyar irodalmából: Fazekas Mihály címmel jelent meg (2001/8, 44-49; elérhető hálózati kiadásban is).

${ }^{4}$ Bíró Ferenc, A felvilágosodás korának magyar irodalma, Bp., Balassi, 1994, 371-388. A monográfia e fejezete tanulmány formában két évvel korábban jelent meg, Főhadnagy Fazekas Úr címmel (It, 1992/4, 653-679.)

${ }^{5}$ Debreczeni Attila, A „kötött” ihletek költője (Fazekas Mihály: Cs. et F.), Tiszatáj, 1998/12 (Diákmelléklet), $1-16$.

${ }^{6}$ Bíró Ferenc monográfiafejezetét, valamint Szilágyi Márton és Borbély Szilárd tanulmányait említhetjük. SzILÁGyi Márton, Kegyelem és erőszak: Fazekas Lúdas Matyija, Alföld 2002/7, 41-57, újraközlés: Uö, Határpontok, Bp., Ráció, 2007, 164-182. (idézeteink ez utóbbiból valók); továbbá BoRBÉLY Szilárd, Debre és Döbrö: Jegyzések és emlitések a Lúdas Matyi olvasásához = Margonauták, szerk. AmBrus Judit,
} 
és az Árkádia-per ${ }^{7}$ vizsgáltatott friss szemmel. Bécsy Ágnes mindezek alapján perújrafelvételt kezdeményezett, elsősorban Fazekas költészete ügyében, de sajnos csak a probléma felvetéséig és termékeny meglátásokig jutott két publikált tanulmányában. ${ }^{8}$

E tanulmányok sugallatát követi a jelen dolgozat, mikor Fazekas Mihály életmüvének vizsgálatára vállalkozik, kimondottan azzal a céllal, hogy hozzájáruljon egy új értelmezés alapjainak lerakásához. Ez szükségszerủen együtt kell járjon a kritikai kiadás textológiai konstrukciójának lebontásával, ami egy párhuzamosan készült és publikált tanulmányban történik meg. ${ }^{9} \mathrm{Az}$ adott keretek között, amint arra a cím is utal, az életrajzi-kronológiai értelmezést felváltani hivatott új portré megformálásához alkalmas kiindulópontokat szeretnénk meghatározni, valamint vázolni az ezek köré építhető új értelmezői kontextusokat. Az alábbiakban először a textológiai vizsgálatok eredményének, az alább kifejtendőket leginkább meghatározó következtetéseknek a rövid összegzése következik. Ezt követi négy meghatározónak ítélt kontextus kiemelése a Poézis, az Erkölcs, a Tudományok és az Önértelmezés fogalmai köré csoportosítva. Mindegyik esetben kiindulópontként valamely (a textológiai-filológiai vizsgálatok eredményei alapján kiemelt jelentőségünek tekinthető) szövegforrásszövegforráscsoport áll a középpontban, az elemzések döntően ezek paratextuális vagy önreflexív jellegű szövegeiből, szövegrészeiből indulnak ki. Az egyes fejezetek közötti kapcsolatok retrospektíve épülnek ki, a későbbi fejezetek az ott felvetett szempontok szerint mindig visszatekintenek az előzőek kapcsolódó vonatkozásaira. A sorban negyedik Önértelmezések fejezet pedig eleve retrospektív, hiszen maga a kiindulásul választott mü is visszatekintő számvetésnek készült, elemzése során így öszszeérnek és szembesítésre kerülhetnek az addig mondottak. A lehetséges kontextusok felvázolását követő utolsó fejezet az életmü egészére vonatkozó értékelés szempontjait veti fel, s fogalmaz meg a későbbi vizsgálatokat inspirálni kívánó hipotéziseket.

BÁRÁny Tibor, Csörsz Rumen István, Hegedüs Béla, VAdERna Gábor, Bp., rec.iti, 2009, 180-187. Szilágyi Márton újradolgozott kéziratos tanulmányában az általunk hivatkozott megállapítások, szövegrészek nem változtak.

${ }^{7}$ Csetri Lajos, Egység vagy különbözőség?, Bp., Akadémai, 1990; Gyapay László, „A' tisztább ízlésnek regulájival”, Bp., Univeristas, 2001; Bíró Ferenc, A legnagyobb pennaháború, Bp., Argumentum, 2010. E három, alapvetően kritikatörténeti, nyelvújítás szempontú elemzést követően a jelen dolgozatot közvetlenül megelőzően készült saját írás a debreceniség fogalma szempontjából tekinti át a kérdéskört: DEBRECZENI Attila, A debreceniség: Kazinczy és egy nyelvi paradoxon születése = A debreceniség mintázatai: Városi identitás és a kulturális emlékezet rétegei a kora újkortól napjainkig, szerk. BóDI Katalin, FAZAKAS Gergely Tamás, LAPIs József, Debrecen, Debreceni Egyetemi Kiadó, 2020, 24-71.

${ }^{8}$ A már idézett melletti másik tanulmány: Bécsy Ágnes, „Mind egy célra kell sietnünk...”: Fazekas Mihály hagyományai és modernsége = „De mi a népiesség...”, szerk. SAllai Éva, Bp., Kölcsey Intézet, 2005, 347-364.

${ }^{9}$ Debreczeni Attila, Egy új Fazekas-kiadás alapvetése, ItK, 2019/5, 661-694. 


\section{„Ami tudható és ami nem”}

E fejezetcím Szilágyi Márton Uránia-monográfiájábóo ${ }^{10}$ vett idézet. A könyv összegző részeinek elhíresült címe a tisztázó szándékot jeleníti meg igen plasztikusan, mely arra irányul, hogy végre elváljanak egymástól tények és vélekedések. Nem lehetett más a célunk Fazekas esetében sem, mikor elvégeztük a kritikai kiadásban testet öltött és az életmű Julow Viktor-i értelmezését minden vonatkozásban átható textológiai-filológiai konstrukció lebontását. Szögezzük le, hogy a Julow-Kéry-féle kétkötetes kritikai kiadás a kor elöírásait követő, a kor elvárásainak mindenben megfelelö, rendkívül alapos munka, amely lényegében ugyanúgy kimeríti tárgyát, mint a Julowmonográfia. A mai textológiai előírásoknak és elvárásoknak azonban értelemszerűen nem felelhet meg: egyrészt mert modernizált írásmódot alkalmaz (tehát jelenleg nincsen betühív Fazekas-kiadásunk), másrészt mert mereven ragaszkodik a kronológiai elvhez, amelynek megvalósítása saját bevallása szerint is „szinte lehetetlen feladat"11 Fazekas esetében. Az elvégzett revízió a Csokonai- és Kazinczy-életmű kapcsán kialakított textológiai elvek és eljárások ${ }^{12}$ alkalmazásával történt, melynek során megalapozódott egy új, nyomtatott és elektronikus Fazekas-kiadás. Az alábbiakban az új kiadás alapvetését jelentő tanulmány eredményeit foglaljuk össze (néhány ponton szövegszerü átvétellel), s a dolgozat egészében is külön hivatkozások nélkül az ott feltárt szövegforrásokra és megállapított kronológiai rendre támaszkodunk. ${ }^{13}$

A tények és vélekedések elválasztására leginkább a hitelesség és a kronológia terén volt szükség. A filológiai adat rigorózus értelmezése alapján revideálni kellett a szerzői hitelesség kritériumait is, hogy tisztázhatóvá váljon, mely szövegcsoportok és milyen valószínűséggel tekinthetőek Fazekas műveinek. Négy kategóriát különítettünk el a bizonyosan hiteles művektől a hitelesnek nemigen tekinthetőekig (Fazekas Mihály művei, Feltehetően Fazekas Mihály müvei, Bizonytalan szerzőségü művek, Kétes hitelű művek). A költői életmű bizonyosan hiteles körébe 71 szövegforrás tartozik az összes 105-ből, ehhez jön még a feltehetően (de szigorú filológiai kritériumok szerint nem bizonyíthatóan) hiteles 28 forrás. A bizonytalan szerzőségü és a kétes hitelü források száma 3-3. A 105 szövegforrás 88 szövegidentitást alkot, melyekből 63 esetében az egyetlen ismert forrás maga képez identitást, $\mathrm{s}$ a fennmaradó 42 forrás alkotja a további 15 szövegidentitást.

\footnotetext{
${ }^{10}$ Szilágyi Márton, Kármán József és Pajor Gáspár Urániája, Debrecen, Kossuth Egyetemi Kiadó, 1998, 297, 326.

${ }^{11}$ FMÖM I. 190.

${ }^{12}$ Debreczeni Attila, Csokonai költői életmüvének kronológiai rendje, Bp. - Debrecen, Akadémiai, 2012, 13-34; Kazınczy Ferenc, Költemények, s. a. r. Debreczeni Attila, Debrecen, Debreceni Egyetemi Kiadó, 2018, II, 9-20.

${ }^{13}$ A Fazekastól származó idézetek tehát az eredeti szövegforrásokból származnak, ahol nem (néhány prózai írás esetében), ott a kritikai kiadásból, amelyre ilyenkor hivatkozunk. A forrás és az idézet minden esetben azonosítható és visszakereshető a szövegből.
} 
A költői életmű kronológiai rendjére nézve megállapítható, hogy teljes bizonyossággal való keltezésre a források és az identitások esetében is alig van lehetőség: a 88 szövegidentitásból mindössze 6 datálható pontosan, 1 közelítő pontossággal (-tól -ig), 21 hozzávetölegesen (azaz elött, után meghatározással), így 60 esetben bizonytalan a keletkezés ideje, ami nagyjából kétharmados arányt jelent az életművön belül. Ebből 25 esetben, zömében a Lovász Imre 1836-os kiadásában fennmaradt verseknél semmit nem tudunk mondani a keletkezés idejéről. A többinél legalább egy bizonytalan dátum megadható: 1803-?1804 elött, ami az Aprótseprőségek összefoglaló címü és a vele összekapcsolható további kéziratos csomók valószínüsíthetö összeírási idejéhez van viszonyítva. Fazekas költészetének kronológiai rendje valójában tehát nem alkotható meg olyan részletességgel és olyan bizonyossággal, hogy az összefüggésbe hozható lenne az életrajz egyébként ugyancsak rendkívül hiányosan ismert tényeivel. Így viszont az életrajzi alapú értelmezői narratíva, amely jelenleg is döntő mértékben meghatározza Fazekas Mihály költői életművének megközelítését, tarthatatlan.

Ami valamelyest ismert, az a szövegforrás-típusokhoz és azok csoportjaihoz kötődik. A nyomtatványokban megjelent versek kiadásának körülményeiről nem sokat tudunk, a hézagos információk leginkább arról szólnak, hogy nem Fazekas, hanem valaki más volt az, aki a verseket közlésre adta (hírlapi katona-verseit katonatársa, a Lúdas Matyit Kerekes Ferenc, a Nyári esti dalt a Hébében Kazinczy). Igaz, a Lúdas Matyi második kiadása már Fazekas tudtával és jóváhagyásával készült, így autorizáltnak tekinthetö. Lényegében egyedül a Debreczeni Magyar Kalendáriom verseit kapcsolhatjuk egyértelműen Fazekas publikálási szándékához a költemények között, az egész életművet tekintve pedig ilyen még a Füvészkönyv is. A Kalendáriom anyaga (vers és próza egyaránt) mennyiségében a legnagyobb a nyomtatást látottak között. Időben ezek megjelenését az 1819-1828 közötti időszakhoz köthetjük, a versek közül mindössze egy esetben van átfedés más szövegforrásokkal. Magáról a szerkesztésről nem sokat tudunk, s jellegénél fogva az egyes kötetekbe szétosztott anyag sem mutat szerkezeti-kompozíciós összefüggéseket, hiszen nem szövegcsoportról van szó. Ugyanakkor a kalendárium bevezetése, mottóversei és néhány Fazekas által is kiemelt szövege alapján megragadhatónak tűnnek a vállalkozás programos elgondolásai, melyek mégis valamiféle sajátos egységet képeznek az életmű e jelentős korpuszában.

Szerzői szándékot megtestesítő szerkezettel bíró szövegcsoportot az autográf kéziratok között találunk. Az Aprótseprőségek címet viselő kéziratcsomók eredeti lejegyzési rétege tisztázat, amely - mint a cím, a tagolás és az Ajánló Vers egyértelműen mutatja - gyüjteményes összeírásnak készült. Az eredeti lejegyzésen azonos szinü tintával és írásképpel javitások történtek, ezek kisebbik része egyértelmüen lejegyzés közbeni, nagyobb része utólagos korrekció. Ezt követte a csomószámozás, ami a jelenleg ismert sorrendet kialakította, s ami néhány ponton nincs összhangban az őrszavakból kivehető eredeti sorrenddel, ebből következően tehát az eredeti lejegyzésen utóbb még szerkezeti átalakitásnak is történnie kellett. Az átrendezés ténye és az eredeti lejegyzésen végrehajtott javítások együttesen arra vallanak, hogy az eredetileg 
gyűjteményes tisztázatnak indult kézirategység utóbb munkapéldánnyá alakult át, amely szerkezetileg nem volt koherens.

A csomószámozás kilenc csomót, azaz 72 oldalt foglal egy kézirategységbe, melyek közül ma már csak az 1-4. és 8-9. egységek lelhetőek fel, s a kilencedikből hiányzik az egyik ív, összesen így 44 oldalból áll. Idetartozik viszont további egy ív és egy félív (azaz 4 és 2 oldal), amelyeken nincs csomószám, összesen tehát 50 oldal maradt fenn az Aprótseprőségek csomóiból, s ehhez vehetünk még két másik gyüjteményben található, azonos papírminőségü, méretü és írásképü csomót is. Az ezek keletkezési idejéül, mindkét lejegyzési fázisra érvényesen megadott 1803-?1804 dátum első eleme azon alapul, hogy a csomókban bizonyosan 1802 őszén-telén keletkezett versek is vannak, a csomók lejegyzése így nem lehet ennél korábbi. A másik határoló dátum filológiailag már erősen bizonytalan, s pusztán azon alapul, hogy Fazekas utóbb a költészettel való 1805 körüli felhagyásáról tesz említéseket, amivel egy markáns írássajátosság megváltozása is összhangban van.

Hasonló megfontolásokból ugyanezen időszakra tehetjük az Anakreonkák címet viselő, két lapból álló csomócskát. Ezt sorrendileg két másik, szintén anakreoni dalokat tartalmazó csomó előzte meg, melyek anyagukban részben átfedésben vannak az Anakreonkákkal. Az Aprótseprőségek és az Anakreonkák egykor külön-külön összefüggő szövegcsoportjai ma kilenc önálló csomót alkotnak, melyekben 36 versforrás található. Ez a 44 ismert autográf kéziratos forrás több mint $80 \%$-a, s a teljes életmü szövegforrásainak is mintegy a harmada, vagyis már mennyiségét tekintve is jelentős része a költői életmünek. Még inkább meghatározónak érezhetjük azonban azért, mert ez az egyetlen olyan egység, amely (mint azt a kézirat leírása során jeleztük) egyértelműen szerzői kompozíciós szándékot mutat. A kritikai kiadás a versek életrajzzal párhuzamba állított keletkezési sorrendjét látta ebben megtestesülni, e minőségében vált kronológiai konstrukciója alapjává. Bécsy Ágnes felvetette, hogy nem „ciklusépítő szándékot tükröz-e inkább” ${ }^{14}$ e csomó, felvetését azonban nem építette bele gondolatmenetébe. Az alábbiakban először az e gyüjteményes összeírásban testet öltő kompozíciós eljárások feltárására és értelmezésére teszünk kísérletet, melyek a szövegcsoport töredékessége ellenére is kitapinthatónak tűnnek.

\section{Poézis}

(Az Aprótsepröségek kompozíciós elvei)

Cím, ajánlás és még egy paratextus

A kéziratos csomók összetartozó egysége önálló címlappal kezdődik, melyen csak az Aprótsepröségek cím áll nagybetűkkel, szerzői név nélkül, ezt követi ugyancsak önálló lapon a nyolcsoros Ajánló Vers. E paratextusok egyértelmủen utalnak a gyüjtemény

\footnotetext{
${ }^{14}$ BÉcsY, Egy jó költö, i. m., 10.
} 
tudatosan szerkesztett jellegére, $\mathrm{s}$ arra, hogy összeállítója valamely nyilvánosságnak szánta azt. Ez azt jelenti, hogy Fazekas e gyüjtemény összeállításához fogván a költőként való színre lépést fontolgatta. A cím és a gyüjtemény ajánlásban olvasható megnevezése (elmém bimbótskája) lekicsinylö, a bimbótska kifejletlen voltában kezdetlegességre utal, az aprótseprőségek a jelentéktelenséget sugallja. E minősítések a nyilvánosságba lépéskor szokásos szerénység-formulaként ${ }^{15}$ értelmezhetőek, a formula tulajdonképpeni értelme (ha létezik egyáltalán a puszta konvención túli jelentése) a szövegkontextus és a szerkezet által tárulhat fel.

A gyüjtemények élén gyakran állnak invokációs vagy ajánló gesztusokra épülő szövegek, melyek a keretes szerkesztés nyitóelemét jelentik. ${ }^{16}$ Az Aprótseprőségek rendelkezik ajánlással (lezáró keretvers azonban nem maradt fenn vagy nem is volt ilyen):

$$
\begin{aligned}
& \text { Gyakrann sírnak a’ kik írnak } \\
& \text { Hogy kajánok gúnyolodnak; } \\
& \text { A' bőltsebbek, 's méreszebbek } \\
& \text { Véllek nem bajlódnak } \\
& \text { Én meg, elmém bimbótskáját } \\
& \text { Im’ ajanlom a' kajánnak } \\
& \text { Mint ki szentelt gyertyátskáját } \\
& \text { Gyújtá a' Sátánnak. }
\end{aligned}
$$

Az Ajánló Vers kontaminálja az ajánlások két típusát. A költő az ajánlásban gyakran a Múzsához fordul vagy az Olvasóhoz, támogatást kérve vagy a jóindulat elnyeréséért folyamodván, netán Mecénásához vagy valamely tisztelt Nagyemberhez, Baráthoz, akiket magasztal, s akiktől megerősítést, esetleg anyagi segítséget vár. De mikor a költő a 'gonosz szemű olvasóhoz' fordul, akkor a Zoilushoz, az igaztalan kritikushoz címzett ajánlástípus variációját valósítja meg, amelyben a megszólított hibái, a vele való ellentét, netán annak gyalázása dominál. ${ }^{17}$ Fazekas Ajánló Verse e hagyományhoz látszik csatlakozni, hiszen az ajánlás a Kajánhoz szól. A Kaján (melynek elsődleges jelentése ebben a korban: irigy) az antikvitásból eredeztethető költői hagyományrendben az igaz költővel ellenséges világ szimbolikus értelmű alakja vagy megszemélyesítése, így használták a korszak magyar írói, költői is. ${ }^{18}$ Csokonai Ódák kötetének 2. könyvében az ajánló-nyitó vers, az 1802-1804 között készült A’ Múzsához például

\footnotetext{
${ }^{15}$ Lásd erről Pesti Brigitta, Dedikáció és mecenatúra Magyarországon a 17. század első felében, Bp. Eger, Kossuth, 2013, 119-128.

${ }^{16}$ Virág Benedek és Berzsenyi kötetei kapcsán Onder Csaba a variabilitas és a keretfunkció elveinek egymásra épülését emelte ki, hangsúlyozván ez utóbbinak az egység és rend ugyancsak horatiusi követelményének teljesítésében játszott szerepét: Onder Csaba, A klasszika virágai, Debrecen, Kossuth Egyetemi Kiadó, 2003, 79.

${ }^{17}$ Lásd Pesti, i. m., 127, 316-320.

${ }^{18}$ Lásd Gergye László, Múzsák és gráciák között, Bp., Universitas, 1998, 28; SzILÁGyi Ferenc, Csokonai dunántúli tájszógyüjtése, Bp., Akadémiai, 1974, 166-170.
} 
éppen erre az ellentétre épül, mint azt a kezdő- és zárósorok nyomatékosítják: „Múzsám, ne tsüggedj! bár vak irígyeid / Kantsal szemekkel rád hunyorítanak” - „Lát’d! integetnek tiszta barátaid; / Nevednek óltárt a’ maradék emel: / Megpukkad annál a’ kajánság". Nem tudjuk (s valójában nem is lényeges), hogy Fazekas versének közvetlenül van-e köze a Csokonaiéhoz, azt viszont nyugodtan állíthatjuk, hogy az Ajánló Vers első négy sora a Csokonainál (és másoknál is) megjelenő oppozíció-toposzt idézi meg a Kaján alakjával.

A második négy sor, a tulajdonképpeni ajánló gesztus azonban összefonja ezt a jóindulat elnyeréséért folyamodó ajánlástípussal. A versbéli beszélő, aki azonos a gyüjtemény (Aprótseprőségek) szerzőjével, a gyüjteményt (elmém bimbótskáját) éppen az ellenséges világot megszemélyesítő Kajánnak ajánlja, $s$ az ajánló gesztus ezáltal legalábbis idézőjelbe kerül. A jelentésmódosulás az utolsó két sorban idézett mondáson alapul. A mondás (gyertyát gyújt az ördögnek) két fö jelentésben használatos: 1) 'néha a gonosznak is kedvében kell járni, hogy ne ártson'; 2) 'olykor a kellemetlen kötelességet is jó kedvvel el kell végezni. A második jelentés értelmileg nem igazán illik a versbe, az első már inkább, ha azt szó szerint vesszük: így a Kaján jóindulatának elnyeréséért látszik folyamodni a gyüjtemény szerzője. A mondás azonban egy hasonlatba van foglalva, amely hasonlat a Kajánt a Sátánként (ördögként) jeleníti meg, s ez a hasonlítás retorikailag az ellentétébe fordítja a jelentést. Az ajánló gesztus így inkább a címzettel szembeni gúnyként érthető, s ezzel végső soron az irigyhez szóló ajánlástípus érvényesül a jóindulat elnyeréséért folyamodó típus keretei között, sajátosan kontaminált retorikai formában. Mindez pedig mintha idézőjelbe tenné a szerénység-formula lekicsinylő önminősítését is.

A gyüjteményes összeírással összefüggésben létezik egy további szöveg, amely filológiai helyzetének bizonytalanságai ellenére sajátos paratextusként értelmezhető. A Julow Viktor által 'miniatür ars poeticának' nevezett ${ }^{19} \mathrm{Az}$ én poézisom címü költemény a hagyaték mai állapota szerint nem része az Aprótseprőségek gyűjteményének, csak Lovász Imre Fazekas halála utáni kiadásából ismerjük. Címe és önreflexív karaktere alapján akár a gyűjtemény jelenleg hiányzó záró keretversének szerepét is betölthette, de a filológiai tény az, hogy nem tudjuk, benne volt-e eredetileg, s csak annak töredékessége folytán nem maradt ott fenn, vagy egyáltalán nem is volt része annak. Akár így, akár úgy volt, az aprótseprő megnevezés és az Aprótseprőségek cím egyezése miatt az eddig firkálék és az azt látja akárki az e címen összeírt versekre kell vonatkozzék, legalábbis nemigen tudjuk azt másként érteni. ${ }^{20}$

\footnotetext{
${ }^{19}$ JuLow, Fazekas Mihály, i. m., 376-377, illetve 174-175. A verset tehát Julow Viktor kétfelé bontva idézi és értelmezi, egymástól kétszáz oldal távolságra helyezve az önlebecsülö-mentegetőzőként interpretált első négy sort, valamint a korabeli verselési rendszerek ismertetésének kontextusába helyezett továbbiakat.

${ }^{20}$ Ebből több dolog is következik: egyrészt, hogy a verset hitelesnek kell tekintenünk, noha csak Lovász kiadásából ismerjük, másrészt, hogy megírásának ideje is az Aprótseprőségek keletkezéséhez kapcsolható, tehát semmiképpen nem kései összegzés, mint Julow Viktor véli.
} 
Lantosok é? hegedűbe valók? vagy táragatóba?

A’ miket én eddig firkálék; hogy ne hazudjak

Nem tudom én. Aprótseprők azt látja akárki,

És ha dorombba verik sem szégyenlik magokat meg,

A’ melly verssorok egynéhány egyforma betükön

Végződnek; hajdan azokat nevezék magyaroknak

Már azokat ma tzigány ’s kóldús szájába valóknak

Hirdetik. A' Drómó tudná izlésteket édes

Lantosim! A' míg hát e’ per valamerre ledülne,

Írjunk kis Músám pompás tógát viselendő

Verseket is ha tudunk, de azért senkit ne nevezzünk

Kóldúsnak se’ tzigánynak az e’félékbe ha nem fog

Kedvet lelni, mivel zabolát nem szenved az izlés.

A vers három, különböző modalitású közlésre épül (melyeket kurzívval emeltünk ki a 2-3., a 8-9. és a 10-11. sorokban): az első kettő a tanácstalanság kinyilvánítása, elöször saját verseit, majd a korabeli versszerzők véleményét illetően, a harmadik a tanácstalanságon túllépve írásra szólít fel. Az első kijelentést az Aprótseprőségekre vonatkozó reflexió fogja közre a 2-3. sorban, amely ugyanúgy leértékeli a gyüjteményt, mint annak címe és ajánlása a szerénység-formula értelmében. Az ezt körülölelő 1 . és 4 . sor ${ }^{21}$ pedig jelzi, hogy a vers tanácstalanságot kifejező első fő közlése mire is vonatkozik. Hangszerek és poézistípusok társítása gyakori eljárás volt a korabeli és régebbi költészetben egyaránt, a jelen felsorolás formulája inkább a régi énekhagyomány szemléletét tükrözi. A sorjázó kérdések azt firtatják, hogy a szóban forgó versek mire valók, vagyis nem hangnemi, müfaji vagy tematikus összefüggéseket idéznek fel, mint ugyanezen hangszerek kortárs előfordulásai, hanem a használati mód felől tekintenek azokra.

\footnotetext{
${ }^{21}$ A 4. és 5. sor viszonya nem egyértelmű. A központozás szerint az 5. sor a 4. sorban álló főmondat bővítménye, s így a 'doromb' a rímes verselésre vonatkozván a 4. sort az utána következőkhöz kapcsolja. Mivel a pont, vessző, pontosvessző használata a korban egyáltalán nem következetes, s a vers csak Lovász Imre utólagos publikációjában maradt fenn, a jelen központozásban egyértelmű szerzői értelmező szándékot nemigen tételezhetünk fel, érdemes tehát számot vetnünk a másik lehetőséggel is:

És ha dorombba verik sem szégyenlik magokat meg[.]

A' melly verssorok egynéhány egyforma betűkön

Végződnek[,] hajdan azokat nevezék magyaroknak[,]

Már azokat ma tzigány’s kóldús szájába valóknak Hirdetik.

Ez a mondattani tagolás jobban megfelel a szöveg aláhúzásokkal kiemelt belső utalásrendjének, mely szerint a 'magokat' a 3. sorra utal vissza, az aprótseprő versekre, vagyis mindarra, amit addig összeírt, a megismételt 'azokat' pedig pusztán a rímes versekre, hiszen mondattanilag az 'amely' vonatkozó névmáshoz kapcsolódnak. Akárcsak Julow Viktor, magunk is ez utóbbi lehetőséget tekintjük indokoltnak a vers értelmezésében, vagyis a 4 . sort a megelőzőekre vonatkoztatjuk, s az 5. sorban új gondolat kezdetét véljük felfedezni.
} 
A Pöngését koboznak... címü, 17. század eleji vers elemzői ${ }^{22}$ rámutatnak arra, hogy e régi költeményben és az azt körülölelő énekhagyományban a hangszerek közösségi helyek, társadalmi szokások, hangulatok jelölői voltak, melyek magukhoz rendelték a verses szövegeket, egyértelműen jelezvén a felhasználás elfogadott módját. Az én poézisom hangszerkatalógusára vonatkozó kijelentés ('nem tudom én') ebben a hagyományban szemlélve végső soron a gyüiteményes összeírás használhatóságára vonatkozó bizonytalanságot fogalmaz meg, összhangban a firkálék és az aprótseprő kifejezésekkel.

A második és harmadik kiemelt szövegegység egyaránt megszólításokat foglal magában, melyek (miként az első kijelentés) értelmezhetőek az Ajánló Vers analógiájára. A Músa 'kis' jelzője az önkicsinyítés eszköze, a szerénység-toposz megnyilvánulása ezúttal is, $\mathrm{s}$ az 'édes Lantosim' megszólítás ugyanúgy a befogadóhoz fordul, mint az Ajánló Vers, annak külső kritikát elhárító gesztusával pedig nagyon hasonlatos az ízlések különbségére való itteni hivatkozás. Feltűnő, hogy mindkét helyen egy-egy ördöggel kapcsolatos mondás ${ }^{23}$ kerül kiemelt pozícióba, ami a stílusszint szándékolt keverésével és a kedélyeskedő megfogalmazással együtt ironikus-gúnyos hangoltságot teremt. A szerénység-formula így a gyüjteményes összeírás paratextusaiban sajátosan ambivalens kettősség kontextusában értelmezhető, jelentése nem rögzíthető pontosan, folyamatosan egymásba mossa az önreflexiót és a külső megítéltetést, melyet azonban idézőjelbe tesz. ${ }^{24}$

A két megszólítás („édes Lantosim”, „kis Músám”) között elhelyezett közbevetett utalás („míg hát e’ per valamerre ledűlne”) a vers nagyobbik második feléhez jelent kulcsot. Az ötödik sortól kezdődő rész a rímes szótagszámláló és az antik időmértékes verselés vitáját exponálja, s elvetvén a rímes verselést megbélyegző áláspontot, mindkettő művelése mellett hitet tesz, mikor az önkicsinyítő, ironizáló játék során a 'Kis Músához' fordulva írásra buzdít. A versújítási időszak egyik első és elemi vitája idéződik meg a vers kontextusaként, amely hosszan elhúzódott, újabb és újabb hullámokat vetve. Az én poézisom mindkettőt elfogadó álláspontja elég hamar megjelent a vitákban, ezt képviselték például a Magyar Museum szerkesztői, Batsányi és Kazinczy, s ezt vallotta a két debreceni költőtárs, Csokonai és Földi is. A kétszeres vers, vagyis a rímes időmértékes verselés mint a poézis újabb lehetősége azonban nem tűnik fel a versben, noha ez éppen Fazekas debreceni költőtársainak munkáiban különösen hangsúlyos. Gondoljunk csak a Lillára, annak is az előbeszédére: ez

\footnotetext{
${ }^{22}$ Lásd Bitskey István, Pöngését koboznak... = A régi magyar vers, szerk. KomLovszki Tibor, Bp., Akadémai, 1979, 225-234; ZemplÉNyI Ferenc, Müfajok reneszánsz és barokk között, Bp., Universitas, 2002, 142. kk.; SzILAsi László, A sas és az apró madarak, Bp., Balassi, 2008, 48-50; Ötvös Péter, Rajongás és fegyelem nyelvi artikulációi = Szönyi Benjámin 300, szerk. IMRE Mihály, Hódmezővásárhely, Ótemplomi Református Egyházközség, 2017-2018, 95-100. A régi magyar énekhagyomány itt jelzett összefüggéseire és a vonatkozó szakirodalomra Bitskey István, Fazakas Gergely Tamás és Imre Mihály hívta fel a figyelmemet. A hangszerkatalógus Fazekas életművét átszövő konkordanciahálójára a későbbiekben több vonatkozásban kitérünk még.

${ }^{23}$ Itt: Drómó = ördög, azaz ördög tudja.

${ }^{24}$ Mindennek további összefüggéseiről lásd az Önértelmezés című fejezetet.
} 
utóbbit bizonyosan ismerte Fazekas, s maga is gyakorlott volt ilyen versek írásában. E versnem itteni elvi mellőzésének több oka lehet, annál is inkább, hogy költeményről s nem értekezésről van szó, ráadásul ez az egyetlen verselésre vonatkozó önreflexió Fazekas szövegeiben. Ha viszont nem elvi állásfoglalásként olvassuk e részt - amelyre egyébként sem alkalmas -, hanem az Aprótsepröségek paratextusaként, akkor rögtön értelemtelivé válik. A gyüjteményes összeírás ugyanis a versnemek szerinti elkülönülésre és a versformák és témák váltakozásában megnyilvánuló variabilitásra épül, melyek mint fö kompozíciós elvek vehetőek számba a paratextusok mellett.

\section{Verselés és variabilitas}

A gyüjteményes összeírásban érvényesülő rendet elsődlegesen a versnemek határozzák meg. Az Aprótseprőségek egybefüggő 1-3. csomója csak rímes szótagszámláló verseket tartalmaz, az Ajánló Vers utáni első hat leginkább rövidsoros énekformát követ, három közülük kétütemü keresztrímes 8+7-es Faludi-vers, az utolsó költemény páros rímü 12-es, s ilyen az őrszó által jelzett következő is, amelynek azonban nincs már meg itt a szövege. Az Aprótseprőségek 4. csomója az elé kapcsolt töredék félívvel csak antik időmértékes verseket tartalmaz, Vergilius I. eklogájának fordítása hexameteres, ezt követi három alkaioszi strófákból álló költemény és egy második aszklepiadészi strófában. Az Aprótsepröségek 8-9. csomója énekformákban készült rímes szótagszámláló versekből áll, az első három, melyek $A^{\prime}$ tavasz eleje csomóiban is megtalálhatóak, német protestáns ének dallamjegyzését követik, míg a következő zsoltárdallamot, ${ }^{25}$ az utolsó pedig Faludi-vers. A töredékesen fennmaradt Aprótseprőségek-csomóban antik időmértékes versek vannak, az első, amelynek csak a zárószakaszai olvashatóak, alkaioszi, majd egy negyedik aszklepiadészi, s csak az őrszó által jelzetten egy hexameteres költemény. Az Anakreonkák csomóiban anakreoni sorokból álló verseket találunk. Az időmértékes és a rímes szótagszámláló versek egybefüggő csomóként különülnek el a szövegcsoportok töredékesen fennmaradt anyagában, keveredésükre nincs példa, mindez a versnemek szerkezetformáló szerepére utal.

A töredékesség óvatosságra kell intsen az általánosító megfogalmazásokat illetően, ezért érdemes egy pillantást vetni e szövegcsoport és a költői életmű egészének viszonyára. Az Aprótseprőségekben (ajánlóverssel, őrszavakkal számítva) fennmaradt 21 költeményből 13 rímes szótagszámláló, 8 antik időmértékes, az előbbiek között a Faludi-versekből és a protestáns énekversekből, az utóbbiak között az alkaiosziakból és a hexameterekből van 3 vagy annál több. Az életmű 88 verséből 42 rímes szótagszámláló (s időnként időmértékes is, mint arra korábban utaltunk), 40 antik időmértékes, s van 6 verses szöveg, amelyekben különböző versnemek vagy versformák együtt szerepelnek. A rímes szótagszámlálók közül a legtöbb (13) Faludi-vers, a rövid soros versekből csak egy-kettő van típusonként. A hosszú soros versek száma 6, ezek elmélkedő, illetve epikus költemények, a másik nagyobb tömb a változó szótagszámú

\footnotetext{
${ }^{25}$ Julow, Fazekas Mihály, i. m., 182. A dallamjegyzést Hovánszki Mária azonosította.
} 
énekversek csoportja, amelyekhez számítható még a német dallamra, illetve zsoltárformára írott verscsoport is, összesen tehát 14 költemény. Az antik időmértékes versek közül legnagyobb számban a hexameterek (13) és az alkaiosziak vannak (7), valamint az anakreoni versek (10). Megállapítható tehát, hogy az Aprótseprőségek fennmaradt anyaga a versformák arányait tekintve reprezentatív mintája az egész költészetnek, verselés és szerkezet összefüggéseinek vizsgálata így a töredékesség ellenére sem tünik indokolatlannak.

A versnemek és versformák köteteket és azok belső szerkezetét meghatározó szerepe a 18. század utolsó harmadában elemi kötetalkotási elvként funkcionált. A deáki módra készült és a magyar versek a versnemek szerint tisztán elkülönülő két alapvető típust jelentik a verskötet-kiadások első időszakában. ${ }^{26}$ Vannak olyan kötetek is, melyekben a versnemek a belső tagolódást határozzák meg, például Dayka Gábor gyüjteményes összeírása, az ún. Veres Kötet, ahol a versnemek egy-egy könyvet alkotnak, vagy Berzsenyi 1813-as kötete, ahol a rímes szótagszámláló versek ugyancsak önálló könyvben találhatóak. Az Aprótseprőségek e típushoz sorolható, mert ha könyv szerinti beosztás nincs is a szövegcsoportban, az egybefüggően fennmaradt csomók versnemenként különülnek el: vagy csak rímes szótagszámláló, vagy csak antik időmértékes verseket tartalmaznak. Az egyes versnemeken belüli szerkezetformáló elvek azonban az Aprótseprőségekben nem követik sem a deáki módra készült kötetek normatív, sem a magyar versek reprezentációs kiadási gyakorlatát, sokkal inkább a variabilitas horatiusi eljárása tűnik meghatározónak. ${ }^{27} \mathrm{Ez}$ a korabeli kötetek igen nagy százalékában felfedezhető valamilyen mértékben, itt most csak Virág Benedek 1799-es kötetére és Berzsenyi 1808-as összeírására hivatkozunk, melyek többek által több szempontból is említésre kerültek a szakirodalomban Fazekas költészete kapcsán.

Csetri Lajos így fogalmazza meg a Berzsenyi 1808-as kéziratos kötetében felfedezhető, Horatiustól átvett variációs szerkesztés lényegét: „Kéziratcsomója elrendezésében kiemelhetők ugyan tematikai és hangnemi verscsoportok, de többszörös visszatérésben, s egy-egy ilyen kitapintható verscsoporton belül is az elrendezési egymásután elvi alapját láthatólag az adta, hogy a szomszédságba került versek, még ha valamilyen szempontból (témai, hangnemi, versformai) van is köztük rokonság, más szempontokból eltérő elemeket is tartalmazzanak, s így kielégítsék a változatosság gyönyörködtető igényét." ${ }^{28}$ Fazekas az Aprótseprőségek csomóiban valami nagyon hasonlót valósít meg. Az 1-3. csomó Ruszánda nevére írt dalokkal kezdődik, ami már önmagában kizárja a normativitás és reprezentáció elvét egyaránt. Összetartozásukat a 2. és 3. darab utalás jellegü címadása is hangsúlyozza, ugyanakkor versformájuk váltakozik (Ruszánda Moldvai Szép: Faludi-vers; Más: párosrímü 9-es, Más: Faludi-vers). Ezt követi a megelőző verssel azonos formájú, de mitológiai történetet elmondó Danaë címü költemény

\footnotetext{
${ }^{26}$ Lásd ONDER, i. m., 141-155.

${ }^{27}$ Ezekről részletesen lásd uo., 73-93.

${ }^{28}$ CsETri Lajos, Nem sokaság hanem lélek: Berzsenyi-tanulmányok, Bp., Szépirodalmi, 1986, 19.
} 
és a páros rímű 11-esekből álló, tehát hosszabb soros vers, $A z$ érzékenységek énekbenn. Ez már átvezet a következő két páros rímű 12-eshez, amelyek versformájukból adódóan elmélkedő tematikájúak, de az egyik szerelmi, a másik hadi témából bontja ezt ki: Az öröm tündérsége Ámelit emlegeti, az őrszóval jelzett Egy férje elestén kesergö özvegy pedig a sirató vers hagyományához kapcsolódik.

A téma és versforma váltakozása a többi egybefüggő csomóban is pontosan végigkövethetö. A 4. csomó a vergiliusi I. ekloga hexameteres fordításával indul, majd a Horatius rómaiakhoz szóló ódáját imitáló alkaioszi, A’ meg égett nagy Templom falai közt serkent gondolatok jön a sorban. A következő vers is alkaioszi, de eltérö tematikával és hangvétellel ( $A^{\prime}$ Gratiákhoz), míg ezután a verselés módosul (második aszklepiadeszi strófa), a téma jellege kevéssé (Vitéz Csokonay Mihálynak Mihály napra). A csomó utolsó, töredékben maradt verse (A'szerentsés történet) úira alkaioszi, az emelkedett szerelem témaköréhez visszatérve. A 8-9. csomóban elöl álló énekversek, $A$ ' tavasz eleje darabjai után a töredékesen fennmaradt $A z$ én kis kertem következik, amely tematikusan illeszkedik az előzőekhez, de zsoltárdallamra készült, nagyobb lélegzetü, összegzö vers. Az utolsó darab a szintén elmélkedő karakterü Szükségben segítség, amelynek témája feszültségben áll a Faludi-vers egyszerü formájával. A töredékes csomóban töredékesen fennmaradt Egy véres ütközet estvéjén serkent gondolatok a témát megillető alkaioszi strófában készült, ezt a témában és versformában egyaránt eltérő Vég bútsú Amelitöl követi, amely azonban hangvételének szomorúságában az elözőhöz illik. Az Aprótseprőségek csomóitól elszakadt félcsomóban lévő A' meg elégedés méltóságos tárgyának és hangvételének megfelelően alkaioszi strófában készült. A versnemek szerinti elkülönítés elsődleges szerkezeti elve tehát a horatiusi variabilitas elvvel fonódik össze, amely a versformák és az azzal összefüggö témák váltakoztatásával a csomók belső elrendezését formálja meg.

Csetri Lajos idézett könyvében Berzsenyi 1808-as gyüjteményét kimondottan a versnemek és -formák szerinti felosztásban vizsgálta, belehelyezvén ezeket a korszak európai és magyar vershagyományainak kontextusába, mert a verselésben nem puszta technikát látott, hanem a költői művek alkatának hagyományos retorikai megközelítés szerinti meghatározó tényezőjét. Az antik időmértékes formákra nézve megállapítja, hogy az újlatin poétikai tankönyvek által is közvetített hierarchikus rendszerben a versformák alkatilag bizonyos témákra alkalmasak, elsősorban méltóságfokuk szerint. E megközelítés egészen általánosnak mondható a vizsgált korszak egészében, még az ettől elmozdulni látszó olyan szerzők, mint Kazinczy gondolkodását is alapvetően befolyásolja. E szemléletmód érhető tetten az Aprótseprőségek témát és formát váltogató variációs szerkezetében, a Fazekas-költészet antik időmértékes versnemben készült egyik fele tehát túlnyomórészt ehhez a 18. század végére kiérlelt vershagyományhoz kötődik.

A Berzsenyi-gyüjtemény rímes verseit vizsgálván Csetri Lajos megállapítja a Faludi-vers mennyiségi dominanciáját, $s$ azt, hogy a rövid soros versek többnyire dalszerüek, míg a hosszabb soros strófákban (melyek között 12 szótagos sorok is vannak) 
inkább 'borongós, gondolati, elégikus' versek íródtak. Ezek a súlypontok és tematikus megfelelések jellemzőek a Fazekas-költészet rímes szótagszámláló másik felére is. A rímes szótagszámláló versek kis hányada hosszú soros csupán Fazekasnál, s ezek epikus vagy elmélkedő tárgyúak, miként a Gyöngyösi-strófát az 1770-es évek körül felváltani kezdő páros rímű tizenkettős forma általában. A nagyobb részt képviselő rövid soros vagy változó szótagszámú strófák esetében az énekvers jelleg viszont sokkal hangsúlyosabb, mint Berzsenyinél, s ez nemcsak a számszerű dominancia miatt van így, hanem a versek valószínűsíthető dallamkövetö jellege miatt is. Ez ugyan jelenleg még inkább hipotetikus megállapítás, melynek igazolása a kritikai kiadás részletes vizsgálataira vár, de az ismert tények erre látszanak utalni.

Az mindenesetre különösebb kockázat nélkül kijelenthetőnek tűnik, hogy Fazekas rímes szótagszámló verseinek nagyobb része alapvetően a magyar világi énekköltészeti hagyományok elsősorban Faludi nevével fémjelezhető vonulatához, és a protestáns énekköltészethez kötődik. ${ }^{29}$ Az Aprótseprőségek által reprezentált versformák mindkét versnemben olyan hagyományok kontextusában tünnek értelmezhetőnek, amelyek az 1770-es évek körül alakultak ki a magyar irodalomban, s így a későbbi költészeti formakincs alaprétegét képezik. A gyüjtemény kompozíciós elvei és $A z$ én poézisom paratextusként érthető szövege tehát több ponton is egybehangzani látszanak. A cím és az ajánlás önleértékelő gesztusai a vers expozíciójával mutatnak rokonságot, egyaránt a szerénység-formula ambivalens kettőssége jegyében. A hangszerkatalógus által megidézett szemlélet pedig, amely a verses szöveget annak használati módja által közelíti meg, érvényesnek látszik Fazekas más verses szövegei esetében, így a Lúdas Matyinál is.

\section{Erkölcs \\ (A Lúdas Matyi példázata)}

\section{Allegória és példázat}

A Lúdas Matyi Julow Viktor-féle értelmezését alapvetően meghatározó képviseleti-osztályharcos megközelítés a 19. századból eredeztethető 'demokratiai iránymü' koncepciójának örököse volt. Lebontásukat az újabb szakirodalom már elvégezte: az elemzések átértékelték Matyi és Döbrögi jelentőségét a művön belül, inkább utóbbit állítván a középpontba, Matyi pedig a kíméletlen bosszú végrehajtójaként, deviánsként, sőt, a híres gonosztevők életét elmesélő pitaval müfaji hagyományába illesztve jelenítődött meg. A szemléleti fordulat mondhatni nem is lehetne nagyobb, a megközelítések pedig szórtabbak. Kézenfekvően adódik a kérdés, hogy mivel magyarázható

\footnotetext{
${ }^{29}$ Fazekas is írt vallásos éneket a megújított debreceni énekeskönyvbe, amely elöször 1808-ban jelent meg. Fekete Csaba újabban megtalálta a Fazekas által készített ének 1806-os autográf kéziratát. A 'kétszeres verseket' illetően Hovánszki Mária megjegyzései fontos támpontokat jelentettek.
} 
az értelmezések rendkívüli szórtsága és egymást kizáró jellege. Ennek lehetőségét, úgy véljük, alapvetően az allegorikus olvasásmód teremti meg.

Borbély Szilárd saját olvasási pozícióját rögzítő reflexióját lényegében a Lúdas Matyi értelmezési hagyományának egészére érvényesnek tekinthetjük: „A művet funkciója szerint felnőtt közönség számára készült példázatnak tekintem, retorikai megformáltsága alapján pedig tanító parabolának [...]. [A] müvet pragmatikus, tehát allegorikus intencionáltságú szövegként fogom fel, amely szándékai szerint túllép az elokvencia határain." ${ }^{30}$ A Lúdas Matyi történetét allegóriaként olvasva a képviseleti elv szinte automatikusan válik a példázatos-irányzatos értelmezés alapjává. Ebben az állandósult interpretációs modellben a változó elemet az jelenti, hogy mely szereplők és a történet mely elemei lépnek előtérbe, $s$ határozzák meg a belőlük kibontható másodlagos jelentéssel a mü egészének tulajdonított eszmei tendenciát/irányt/példát, amely így igen sokféle és egymással össze nem egyeztethetö lehet. Magából az allegorikus interpretációs modellből kell tehát kilépnünk, $\mathrm{s}$ a müvet nemcsak funkciója, hanem retorikai megformáltsága szerint is példázatnak kell tekintenünk, minthogy az elsődleges források paratextusaiban egyértelmüek az erre való utalások.

Az első kérdés természetesen a paratextusok hitelessége, vagyis, hogy a befogadás mellett vajon a szerzői intenció szempontjából is figyelembe vehetőek-e. A Lúdas Matyi Fazekas visszaemlékezése szerint 1804-ben született, ezt a szövegállapotot azonban egykorú autográf vagy autorizált forrás nem őrizte meg, egy 1808-as másolatban és a Fazekas tudta nélkül készült, nem ismert forráson alapuló 1815-ös kiadásban vélhetjük ezt felismerni. Az életműben (a szétszórtan nyomtatásba került néhány költemény mellett) az egyetlen Fazekas tudtával és akaratával megjelent önálló verses kötet a Lúdas Matyi 1817-es második kiadása. Ez a Fazekas által 1814 körülinek mondott, ugyancsak nem ismert kéziratos átdolgozás figyelembevételével készült, s egészében autorizáltnak tekinthető, noha Fazekas egyetlen ismert vonatkozó levelében sem tér ki tételesen a kiadvány minden elemére. A mű mindkét kiadásában szereplő alcím regeként határozza meg a műfajt, ami múltban játszódó verses történetet jelentett. Fontosabb műfaji kódot képvisel a Phaedrustól származó mottó, amely a példázatos-tanító (állat)mese hagyományába illeszti a művet. E mottó mindkét kiadásban szerepel, így - ha a kiadótól, Kerekes Ferenctől származik is eredetileg - a második kiadás által autorizáltatott.

Borbély Szilárd idézett gondolatmenetében azonban megjegyzi, hogy a „meseként olvasás utólagos kódja félrevezető", s talán azért nem fejti ezt ki bővebben, mert kimondatlanul is ráhagyatkozik Szilágyi Márton vonatkozó okfejtésére. Szilágyi Márton szerint a mottó „tudatos reflexió egy olyan irodalmi elóképre, amelyet a Lúdas Matyi nem kíván követni”, s állítását azzal indokolja, hogy a mű „nem zárul olyan tanulsággal, amely a történet fabuláris szintjét egyértelmű diszkurzív zárlattal látná el”, vagyis így nem kapcsolódik bele az állatmese „morális töltetű, példázatos

\footnotetext{
${ }^{30}$ BorbÉLY, i. m., 180.
} 
szövegtradíció"-jába. ${ }^{31}$ Szilágyi Márton ugyanis az értelmezésében egyébként kitüntetett szerepet játszó zárlatot egyértelműen és teljesen Döbrögi szólamaként, s így a történet szerves részeként olvassa. ${ }^{32}$ Véleményem szerint azonban csak a zárlat első teljes hexameterének végéig terjedő rész („Az Isten / Így bánik, ’s bánjon valamennyi kegyetlen Urakkal") Döbrögi szólama, ahogy erre a következő sor elején utal a narrátor („Ezt mondván”). Innentől fogva végig a narrátor szól, vagyis tőle hallható a Döbrögi további sorsáról tudósító néhány zárósor, s ezek valójában nem történést, hanem egy állapotot írnak le, amelybe Döbrögi átlépett. A narrátor kommentárja ezt az állapotot egyértelműen követendőként jeleníti meg („és törvénytelenül nem bánt, hanem úgy a' hogy illik, / Ember társaival; jól is végezte világát"33), vagyis Döbrögi megváltozását példaként állítja az olvasó elé. E befejezés kétségtelenül nem kifejtett diszkurzív zárlat, viszont a fabuláris szinthez sem sorolható egyértelmüen, mert tanulságot von le, még ha némiképp kurta-furcsa lezárásaként is az elmesélt történetnek.

A harmadik paratextuális elem a kiadó Kerekes Ferenc előszava, amely a második, autorizált kiadásban is benne maradt, immár Elöljáró-Beszéd az első Kiadáshoz címmel..$^{34} \mathrm{~A}$ kiadás indokaként Kerekes a mü megformálásának érdemei mellett felhozza, hogy „Döbrögi Úrnak / Példátlan példás megjobbúlása is egybe / Úgy szívemre hatott", ami egyértelmü reflexiónak tekinthetö a mü zárlatára. A mottó mellett tehát a mü zárlata és a zárlatot előrevetítő kiadói előszó is a példázatként való olvasás stratégiáját kínálja fel az olvasónak. A negyedik paratextuális elem a szerzői előszó, amely természetszerűleg csak a második kiadásban található meg, s épp ezért, mert kimondottan e kiadáshoz készült új szövegről van szó, a szerzői intenció tudatos megnyilvánulásaként értelmezhető. A szerzői előszó első fele a mű jelentésének diszkurzív kifejtését adja, a példázat müfaji kódjának megfelelően, egybehangzóan a mottóval és a kiadói előszóval. Ha tehát a mű végén esetleg némiképp kifejtetlenül szólaltatja is meg a narrátor az elmesélt történet jelentését, az előszavakkal és a mottóval együtt ez mégis mintegy összhangzó keretet képez.

A paratextuális elemek a példázat (exemplum) hagyományrendjébe tartozó tanító (állat)mese műfaji kódját kínálják fel, nem az allegóriáét, $\mathrm{s}$ a hexameteres versforma is inkább erre utal, semmint az eposzra. ${ }^{35} \mathrm{Az}$ állatmese a 18 . század végének népszerü müfaja, számos önálló könyv jelent meg Aiszóposz és Phaedrus meséinek fordításával,

\footnotetext{
${ }^{31}$ SzILÁgyi, Határpontok, i. m., 176.

32 „Célszerü Döbröginek a harmadik verés után elhangzó kommentárjából kiindulni”, s itt idézi a teljes utolsó hat és nem egészen fél sort. Uo., 178.

${ }^{33} \mathrm{Az}$ első változattal való összevetés a lényeget tekintve nem módosítja ezt az értelmezést, csak ott egy fokkal gyengébb e narrátori pozíció megjelenítése.

${ }^{34}$ Szilágyi Márton jogosan hívja fel a figyelmet az ezt az előbeszédet is kiadó textológiai gyakorlat zavart keltő hatására, de az is kétségtelen, hogy ez az előbeszéd szerves része a szövegforrásnak, így nem elhagyása lehet a járható út, hanem a szerzőség egyértelmű jelzése magában a közlésben, tipográfiai eszközökkel.

${ }^{35}$ Borbély, i. m., 182.
} 
illetve az ő modorukban készült mesékkel. ${ }^{36}$ Feltűnő az is, hogy milyen nagy számban vannak a fordítók, szerzők között a protestáns felekezetekhez tartozók (egyébként már a reformáció kora óta). Az állatmese az exemplum-irodalom kedvelt területe, nagy teret biztosít a fabuláris szint önállósulására, szórakoztató-gyönyörködtető funkciójának kibontakozására. A Lúdas Matyi mesei eredetű története ${ }^{37}$ a példázat olyan változatát képviseli, amelyben a fabuláris szint lényegében uralomra jut, s a tanulság, amelyet példáznia kell, a paratextusokba szorul. Ezért is nyomulhatott előtérbe az allegorikus értelmezés, noha a paratextusok müfaji kódjai egyértelműen kijelölik az adekvát olvasásmódot. A jelentésképzés tehát retorikailag is elválik a fabuláris szinttől, nem a történetelemek önmagukon túlmutató jelentésekkel való megfeleltetése a felkínált olvasásmód, hanem az önállósággal bíró történetegész és az ettől elkülönülő diszkurzív jelentésadás egymásra vetítése.

\section{Kegyelem és törvény}

A Lúdas Matyi történetének kifejtett értelmét a szerzői előszó bocsátja előre legteljesebben. E paratextus első 10 és fél sora múlt-jelen ellentétre épül („Hajdan ütlekkel magyarázták a’ mi Atyáink, / Hogy mi az alsó rend törvénnye” - „Elmúlt a’ vad ido””), amely az eddigiekben alapvetően a történés idejének meghatározása szempontjából vétetett figyelembe az értelmezésekben, $s$ amely kapcsán kiemelt kérdés volt, hogy a hangnem mennyiben tekinthető ironikusnak a jelen vonatkozásában. A múlt-jelen ellentétben azonban időtlen, általános érvénnyel bíró tanítás jelenik meg: a kegyetlen és törvénytelen uralkodás bosszút, azaz lázadást szül, amit kegyelemmel és törvényesen uralkodva lehet elkerülni. Ez a tétel a példázat jelentése, amely az első versszak végén egy közbevetés által explicite összekapcsoltatik Matyi történetével. A többi paratextus e tézis valamely vonatkozását vetíti a fabuláris szintre, hol Matyi, hol Döbrögi példázatos értelmezésével. A mottó Phaedrus-idézete $A$ róka és a sas első két sora, amely a tanulságot fogalmazza meg: „Póroktul óvakodj, bármely fő pólczra lépsz, / Mert könyen áll bosszút a gyors s fogékony ész."38 A kiadói előszó pedig Döbrögi megjobbulását emeli ki, elörevetítve a zárlatot, amely a megjobbulást a szerzői előszóval összhangban a kegyelem és a törvény fogalmaival hozza összefüggésbe.

A kegyelem szó a zárlatban elsődlegesen az uralkodás módjára vonatkozik ('kegyelmesen, kegyesen'), amelynek itt kimondottan a viszont-erőszak elkerülése a

\footnotetext{
${ }^{36}$ Lásd minderröl részletesen Ember Nándor, A magyar oktató mese története 1786-tól 1807-ig, Bp., Athenaeum, 1918.

${ }^{37}$ A történet és a lehetséges forrásmesék kapcsolatáról, az eltérések jelentőségéről a kompozíció eredetisége szempontjából lásd SzILÁGyı, Határpontok, i. m., 173-177, föleg: 176.

${ }^{38}$ Phaedrus Augustus szabadosa Aesop nyomán s modorában írt meséi, ford. Mocsy Antal, Kecskemét, 1855, 40. (I. 28.). A mottó: „Quamvis sublimes, debent humiles mutuere, / Vindicta docili quia patet solertiae." Julow Viktor 1982-es népszerü kiadása Terényi István 1961-es fordítását közli a föszövegbe illesztve, pontos helymegjelölés nélkül (a kritikai kiadásban nem találtunk fordítást sem), ez azonban éppen a fő vonatkozás szempontjából nem elég pontos, hiszen a „humiles”-t „szegény”-ként fordítja.
} 
közvetlen célja: „kegyelemmel akarván / Ójni magát ezután az erőszak tételek ellen”. A 'kegyelem' így egyértelműen a két sorral előbb Döbrögi által mondottakkal képez ellentétet, ahol is a 'kegyetlen urak' említödnek. Ehhez az ellentéthez társul az a másik megállapítás, hogy Döbrögi megjavulása után 'törvénytelenül nem bánt embertársaival', hanem 'úgy ahogy illik', vagyis törvényesen. E szó ugyan nem szerepel itt, de fosztóképzős alakja egyértelmüen ide idézi, a szerzői előszó pedig ki is mondja, hogy mikor elmúlt a kegyetlenségekkel teli 'vad ido”, akkor „Szent a’ Törvény”. A Lúdas Matyi példázatának közvetlen tanulsága szerint a törvény és kegyelem a bölcs fejedelmek uralkodásának sajátja, amellyel elkerülhető 'az alsó rend' lázadó bosszúja, mert az alávetettek elégedettségét eredményezi („van bizodalma Hazánknak / Bölts Fejedelmeiben”).

A Lúdas Matyi paratextusaiban megfogalmazott tétel feltűnik a költői életmű más, hangsúlyos helyein is. Az 1805-ös Cs. et F. címü vers harmadik nagy egységében a földi rossz, kegyetlenség, erőszak a vezetők felelősségével ok-okozati viszonyban áll: „Mert fejedelmei rá kapatták”; „Mert fene Tigrisek a’ Vezéri”, vagyis általánosítva: „A' viz felyülröl árad alá”, épp ezért: „Bóldog halandók kiknek az ég kegyes / És bölts Vezért ad.” A 'kegyes' jelző egyértelműen a Lúdas Matyi zárlatát idézi, akárcsak az Aprótseprőségek 8-9. csomójának fontos darabja, az életmü egyik összegző versének számító Az én kis kertem zárlata:

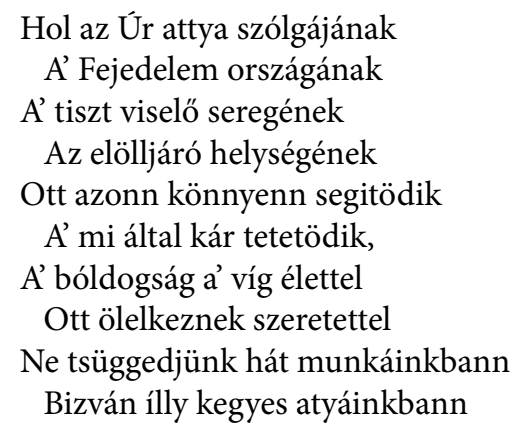

Fazekas költői életművének e markáns szólama kapcsán sokféle értelmezés felvetődött már, leggyakrabban a felvilágosodás fogalmának felhasználásával (felvilágosodott humanizmus, filantrópia, jozefinista paternalizmus stb.). Hozzátehetjük ezekhez, talán szorosabb kontextusként a Volksaufklärungnak a 18-19. század fordulóján Magyarországon is megjelenő irodalmát, amelyben kitüntetett téma az alávetettek forrongásainak elkerülése, megelőzése, s ezzel összefüggésben a jó kormányzás felelössége. ${ }^{39}$ Fazekas közvetlen kapcsolatban is állt a Volksaufklärung hazai irodalmának

\footnotetext{
${ }^{39}$ Kovács Ákos András, Volksaufklärung és politikai nyelvek Magyarországon a 18-19. század fordulóján = „Politica philosophiai okoskodás:. Politikai nyelvek és történeti kontextusok a középkortól a 20. századig, szerk. Fazakas Gergely Tamás, Miru György, Velkey Ferenc, Debrecen, Debreceni Egyetem, 2013, 175-192. A tanulmány a szerző PhD-értekezésének egyik fejezete, a világhálón elérhető a Volksaufklärungról szóló disszertáció egésze.
} 
egyik fontos darabját 1806-ban megjelentető Cserey Farkassal, éppen a mü megjelenésének idején. ${ }^{40}$ Döntő filológiai érveket azonban e kontextualizálás mellé sem tudunk felsorakoztatni, az érvelések hasonlósága mellett pedig lényegi eltérések is mutatkoznak, épp ezért az értelmezésbe további összefüggéseket szükséges bevonni.

Az eredetileg az Aprótsepröségekhez tartozott, de attól nem ismert módon elszakadt csomófél A' meg elégedés címú verset tartalmazza, amelyben a Lúdas Matyi és a vele összefüggésben idézett versek tanulsága ugyancsak megjelenik:

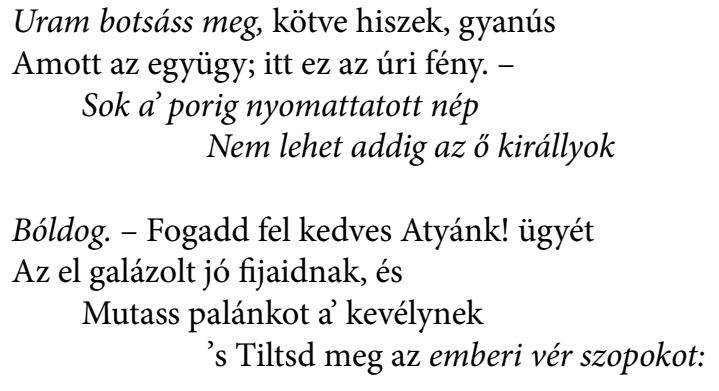

Az ódai szóláshelyzet megszólítottja, a Megelégedés mellett a szövegben többször feltünik, így folytonosan jelen van egy másik megszólított ('Uram', 'Atyám'), aki a 2-3. szakaszban a 'szeretet kimeríthetetlen nagy kútfejének' neveztetik. A horatiusi allúziók mellett a vers poétikai alapkarakterét az imahelyzet és az Úrral való perlekedés végigvonuló szólama határozza meg, ezt látjuk az idézett részben éppúgy, mint a két versszakkal korábbi allúzióban is („Atyám ne kisérts, söt szabadits meg a / Gonosz kezektôl"). Az 'emberi vérszopók'-tól szenvedő 'porig nyomattatott nép' érdekében a beszélő oltalomért a bölcs és kegyes fejedelemhez mint evilági instanciához fordul, ami a Lúdas Matyi példázatával tökéletesen egybehangzik, de ez itt jelzetten a zsoltárköltészet hangján szólal meg. Az 'emberi vérszopók' a Károli-biblia jellegzetes, sokszor előforduló kifejezése, a 139. zsoltár 19. versére pedig közvetlen utalásként is értelmezhető Fazekas ódájának idézett szöveghelye („Hogy-ha el-vesztenéd, Isten, a’ hitetlen embert: a' kegyetlen vér-szopók el-távoznának én-tőlem”" ${ }^{14}$ ). Az alattvalókkal való kegyes és kegyetlen bánásmód ellentéte mindezáltal a bün és erkölcs morálteológiai kontextusába vonódik.

Szilágyi Márton Döbrögi megjobbulását a bünökért való vezeklés utáni megtisztulásként értelmezi: a „»kegyelem « szónak tehát aligha véletlenek a teológiai implikációi: a Lúdas Matyi erősen ragaszkodik egy olyan erkölcsi világrendhez, amelyben a morál

\footnotetext{
${ }^{40}$ Fazekas Csereynél tett látogatására lásd Cserey Kazinczynak írott 1806. május 3-i levelét. KAzINCzY Ferencz levelezése, s. a. r. VÁczy János, Bp., MTA, 1893, IV, 142., 916. sz. (a továbbiakban KazLev.) Vö. még Fazekas levelét Csereynek (FMÖM II. 95.).

${ }^{41}$ Pethe Ferenc 1794-es utrechti kiadása, 511. A bibliai szóhasználatra más összefüggésben lásd Kovács Sándor Iván, „Már az ég bóltját sikeretlen ércznek képzelénk”: Magyarázat Fazekas Mihály verssorához, It, 1980/3, 783-788.
} 
alapja kizárólag a Gondviselés működése lehet"42 A bűn és bűnhődés providenciális sémája általában is érvényesülni látszik Fazekas költeményeiben, nem korlátozódik a jó kormányzás eddig idézett tematikájára. Az Egy véres ütközet estvéjén serkent gondolatokban a háborúskodást indító nagyok (akiket másutt éppen 'vérszopóknak' ne$\left.v z^{43}\right)$ a 'kárhozandók útjára' léptek, ahelyett hogy 'égbe vivő nyomokat keresnének'. A bủn leggyakrabban (akárcsak Csokonainál) a hagyományos erénytani katalógus fogalmaiban ölt testet, úgy mint irigység, kevélység, bujaság, fösvénység (pl. Az én kis kertem, Szükségben segitség, Önnszeretet, A' tavasz eleje).

$\mathrm{Az}$ ezekkel szembeállított erkölcs égi eredetű („Áldjuk mennyei kutfejét / Erköltsünknek”; „esküszöm / A' mennyekre, hogy a’ tőlök alá lejött / Erkölts szent nyomait [...] / nem hagyom-el soha"), követése belső megelégedést szül és az evilági boldog élet záloga („kérjük az ég urát, / hogy bóldog legyen életek / A’ virtust követők lelki barátinak"). ${ }^{44} \mathrm{Az}$ Álom címü versben leírt álombéli út az égbenyúló hegyen, egy kert közepén álló kápolna felé pedig az üdvözülés allegóriájaként érthető ('mennyei tzél, melyre teremtetett'), hiszen egyértelműen a telosz térbeliesítéséről van itt szó („Nints olly tzél az egek bóltja alatt, hova / Baj nélkül szabad eljutni, az út nehéz / Vóltán a’ ki megijjed, / Válasszon gyepesebb nyomot"). A Lúdas Matyi példázata tehát, úgy véljük, megalapozottan vonható a legáltalánosabb morálteológiai összefüggések körébe: a jó (atyai) kormányzás felelősségét kimondó közvetlen tanulság általánosabb értelemben a bűn és bűnhődés providenciális sémája szerint érthető, végső soron pedig az életmü egészét meghatározó, teleologikusan elgondolt erkölcs fogalmához rendelődik. Az erkölcs így a Lúdas Matyi közvetlen tárgya és legfőbb vonatkozási pontja is egyben, hiszen az exemplum hagyományrendje szerint értett 'szép hangzatú erkölcs' a 'Mindentudó fö bölcsességét nyilvánítja meg az emberi világban. Amint a tudományok teszik azt a természeti világra vonatkozóan.

\section{Tudományok \\ (A Debreczeni Magyar Kalendáriom programja)}

\section{Bévezetés és mottóversek}

Fazekas Mihály életművének egyik legnagyobb forrásbázisa a Debreczeni $\mathrm{Ma}$ gyar Kalendáriom 1819-1828 között kiadott tíz kötete. Fazekas maga szerkesztette, de sajnálatos módon a szerkesztés részletei lényegében ismeretlenek, néhány vonatkozó adat maradt fenn csupán, s most került elő az 1821-es kötet saját kezűleg

\footnotetext{
${ }^{42}$ SZILÁgyi, Határpontok, i. m., 179.

${ }^{43} \mathrm{Az}$ Ama nemzetek vérében... kezdetű versben, itt pedig 'a vér szomja hevíti' őket.

${ }^{44} \mathrm{Az}$ idézetek az Éljen a' barátság! című vers végéről valók, melyet Lovász Imre adott ki (s a következőt is).
} 
korrektúrázott példánya. ${ }^{45} \mathrm{~A}$ szövegforrások többsége szépprózai vagy értekező írás, verses közlemény csak mintegy tíz található közöttük. Fazekas a szerzőség megjelölését indoklást kívánó kivételnek tekinti a kalendárium esetében ${ }^{46}$ így egyrészt a közlemények nagyobb részének szerzői hitelessége bizonytalan, másrészt amit megjelöl, annak szerzőségét épp ezáltal fontosnak véli hangsúlyozni, ezért kiemelt figyelmet érdemel. Ilyenek a versek (1824-től kezdődően), a prózai írások közül pedig az Esmérkedés a csillagos éggel az 1826-os kötetből (amelynek folytatásai a következö két évben jelentek meg), illetve ugyancsak az 1826-osból A Debreczeni Kalendáriom tisztelt kedvellöihez, melyben az 1819-ben és 1820-ban elöször névtelenül publikált, majd itt monogrammal újraközölt programverseit mottóverseknek nevezte. S jellegéből adódóan hitelesnek tekinthető a monogram hiánya ellenére is a Kalendáriomhoz írott szerkesztői Bévezetés (a kor szóhasználata szerint nevezzük így, mert saját címe nincs), amely a mottóversek mellett a legfőbb önreflexív szöveg. A Debreczeni $\mathrm{Ma}$ gyar Kalendáriom megközelítésében tehát érdemes ezek értelmezéséből kiindulni. Ez amúgy is indokolt, hiszen a szakirodalom a szórványos említéseken kívül alig szentelt nekik figyelmet, aminthogy a Kalendáriom leíró ismertetésére is leginkább csak egy differenciálatlanul használt felvilágosodás-fogalommal kapcsolatba hozott, az alsóbb társadalmi rétegeket megcélzó ismeretterjesztés összefüggésében került sor, ha sor került, alapvetően Julow Viktor összefoglalása alapján.

A Kalendáriom „Bévezetésének” legfőbb tárgya az a hiány, amelyet a mellette közölt mottóvers a címébe is emelt (A Debreczeni Első Kalendáriomba, mellyböl az időjövendölés kimaradt). Az első bekezdés tömör célmeghatározása egy félmondattal jelzi ezt, majd a következő két hosszú bekezdés a 'helytelen jövendőmondások' eme bejelentett kihagyását indokolja. Az érvelés fő kontextusát a kalendárium mint kiadványtípus jelenti, az érvelés kitér annak funkcionális követelményeire és saját vállalkozásának előzményeire, hivatkozván Mária Terézia hasonló szellemű első rendeletére is, amelynek azonban kevés foganatja lett. A negyedik bekezdés egyetlen költői kérdésbe süríti a jövendölések káros voltával kapcsolatos álláspontját, majd a záró három rövid bekezdésben szinte tézisszerűen összefoglalja a Kalendáriom célkitűzését, reflektálva a szöveg elején központba emelt és mindvégig tárgyalt hiányra: „kalendáriumunkat pedig az üres levegőből merített jövendőmondások helyett gyönyörködtető, szívet nemesítő, tanító és közhasznú toldalékokkal kívánjuk kedvessé

\footnotetext{
${ }^{45}$ A Debreceni Egyetemi és Nemzeti Könyvtárban található példányról nem tud a teljes kalendáriumi anyagot áttekintő újabb dolgozat sem (Csató Beáta 2009-es magiszteri dolgozata a Bécsi Egyetemen, amely az interneten elérhető), csak egy 2011-es szabadegyetemi előadás videofelvételében találtunk erre vonatkozó szóbeli utalást, mely a 20110524 Fazekas Mihály csillagászata (Székács Vera) címen kereshető. Mind Csató Beáta dolgozata, mind Kovács I. Gábor összefoglaló munkája (Kis magyar kalendáriumtörténet 1880-ig, Bp., Akadémiai, 1989.) Julow Viktor monográfiájának vonatkozó fejezete alapján foglalkozik a Debreczeni Magyar Kalendáriommal.

${ }^{46}$ Fodor Gerzsonhoz írott, később idézendő levelében (FMÖM II. 110.).
} 
és érdemessé tenni." ${ }^{47}$ A mottóversek lényegében ugyanezt a logikát követik, csak a kiadványtípus részleteiben való elmerülés helyett inkább a babonaság-világosság, gyermeki kor-felnőttkor metaforikáját előtérbe állítva indokolják a kalendáriumi időjóslás elhagyását.

A Kalendáriom tartalmilag maradéktalanul megfelelt kitűzött céljainak. A számozatlan oldalakból álló kötetek szerkezetileg meglehetős állandóságot mutatnak, csak az első két-három évben vannak érdemi ingadozások. A naptárt tartalmazó első nagy egységet követi a Tóldalék (az utolsó két évben is, noha ekkor e cím elmaradt), amely maga is több részből tevődik össze:

- az uralkodóház személyi-családi viszonyainak áttekintése;

- az államszervezet főbb hivatalviselőinek áttekintése;

- tudományos-ismeretterjesztö (csillagászati) és szórakoztató (novellisztikus) írások és/vagy

- versek;

- Bartha Boldizsár Debrecen-történetének közlése (1822-től, folytatásokban);

- Rejtett szók (azaz verses rejtvények);

- vásárok felsorolása;

- postautak felsorolása.

A Tóldalékok tehát „gyönyörködtető, szívet nemesítő, tanító és közhasznư” szövegtípusokat tartalmaznak, s közöttük is meghatározóak a tudományos-ismeretterjesztő jellegü írások, amelyek a kihagyott asztrológiai jóslások helyét töltik be, és szinte kizárólagosan csillagászati témájúak ${ }^{48}$ csak a folytatásos Debrecen-történet tartozik még e típusba. ${ }^{49} \mathrm{E}$ 'tanító' szövegek mellett kaptak helyet a 'gyönyörködtetö, szívet nemesíto' versek és a szépprózai írások, valamint a 'közhasznú' ismereteket közlő adatsorok. ${ }^{50}$

Fazekas Fodor Gerzsonhoz a Kalendáriom tárgyában írott 1826. április 22-i levelében így indokolja e kiadványtípus választását: „Az én célom csak az, hogy csekély ismeretemet kedves nemzetemmel közölhessem, ez pedig ítéletem szerint könnyebben elérhető nálunk a kézben forgó kalendárium által, mint akármely kész munka kiadásával, melynek csak az lenne sorsa, ami a tömérdek munkával készült

\footnotetext{
${ }^{47}$ FMÖM II. 35.

${ }^{48}$ Ezek forrásairól nem szól egyáltalán a szakirodalom, de az említett szabadegyetemi előadásban utalás hangzik el arra, hogy Lalande és Bode korszerünek mondható szakkönyveire vezethetőek vissza, legalábbis egyezően téves adataik erre vallanak. Hozzátehetjük még ehhez a személyi összefüggések miatt Karap Péter debreceni csillagászati kiadványát is. Fazekas a Kalendáriom mellett, attól különállóan jelentette meg Tsillag óra című, főleg táblázatokat tartalmazó füzetét, melyet a kritikai kiadás fotómásolatban közölt.

${ }^{49}$ Bartha Boldizsár történeti munkájáról van szó, melyet Csokonai is ki akart adni, lásd CsokonAI ViTÉz Mihály Összes Müvei, Feljegyzések, s. a. r. BorbéLy Szilárd, Debreczeni Attila, Orosz Beáta, Szép Beáta, Bp., Akadémiai, 2002, 205-211, 529-531.

${ }^{50}$ Szilágyi Márton hívta fel figyelmemet, hogy ezek a név- és adatsorok a sematizmusok kiterjedt hagyományába tartoznak, amelyből a tiszti szótárak is kinőttek; mindennek jelentős szakirodalma van.
} 
Fűvészkönyvnek." ${ }^{11}$ Kiérződik a sorokból valami keserüség a Füvészkönyv sorsa miatt, ${ }^{52}$ de a belátás lényegét tekintve túlmutat ezen, hiszen a közönséghez való leghatékonyabb eljutás lehetőségét mérlegelve teszi le voksát a tudós könyvek helyett a népszerű kalendárium mellett. A programszövegekben megfogalmazódó olvasóképzetek pedig a megcélzott közönségre nézve jelentenek fontos támpontokat. A tudós hazafiság beszédmódjának formuláit alkalmazva e levélben 'kedves nemzetem' szerepel, a Bévezetés az „Érdemes Hazaf””-t szólítja meg, majd azt a reményét fejezi ki, hogy kiadványa „mind a tudós, mind az együgyü publikum elött" kedvességet nyer. Mindezek alapján legalábbis árnyalandó az a nézet, amely a Kalendáriomot elsőrendűen és kimondottan a népnek, a parasztságnak szóló periodikaként értelmezi. A minél szélesebb olvasókörhöz való eljutás célkitűzése legfeljebb e rétegek bevonásának szándékát jelenti, nem pedig a kizárólagos feléjük fordulást, aminthogy a hatókörben sem csak Debrecenre és környékére számít, hanem a 'két magyar hazára'. A fogadtatásról rendelkezésre álló adatok visszaigazolni látszanak e törekvést, a 6-7000 példány igen jelentős számnak mutatkozik. ${ }^{53}$

A közönséget illető célkitűzések messzemenően összhangban állnak a Kalendáriom közleményeivel. E szempontból a Tóldalék anyagát leginkább az Uránia örökösének tekinthetjük ${ }^{54}$ semmint más korabeli kalendáriumok rokonának. Másfelől viszont a Mindenes Gyüjtemény szerkesztői megfontolásaival láthatjuk a folytonosság szálait, mert a Kalendáriom sokkal inkább ennek osztatlan tudományfogalmához, s nem az Uránia csinosodás-programjához hasonlatos. E hagyományosnak mondható tudásszerkezet jelenik meg a jövendőmondások elvetésének indoklásaképpen a Bévezetés és a mottóversek világosság-metaforikájában, ezért nem rokonítható ez a felszíni hasonlóság ellenére sem az Orpheus babona-ellenességével, ott ennek egészen más a kontextusa. ${ }^{55}$

A Kalendáriom tudományfogalmának azonban van még egy további, minden eddig említett folyóiratétól eltérő karakterisztikuma, amely már a Bévezetés költői kérdésében tetten érhető: „Mármost, midőn - Istené legyen a dicsőség! - a magyar égen a tudomány és az értelem világa naponként felsőbb grádusra emelkedik, micsoda lélekkel akarnánk a még eddig rossz szokásban megmaradott időről való jövendölésekkel az együgyűeket vakítani, a tudósok elött pedig magunkat nevetségesekké tenni?” A világosság terjedésére való konvencionális hivatkozás mellett, azzal összhangban feltűnik az Isten dicsőségére való utalás. Ez az összefonódó érvelés az 1820-as második mottóversben kibontva is megtalálható:

\footnotetext{
${ }^{51}$ FMÖM II. 111.

${ }^{52}$ Erről lásd hivatalos jelentéseit 1823-ból és 1825-ből (FMÖM II. 120-125.).

${ }^{53}$ Fazekas írja A Debreceni Kalendáriom tisztelt kedvellőihez címü 1826-os közleményében, hogy kiadványa megjelenése óta „mindég reménységünket feljülhaladó kedvességgel is fogadtatott” (FMÖM II. 50.). Julow Viktor a debreceni nyomdatörténeti monográfia alapján adja meg a példányszám-adatokat. Julow, Fazekas Mihály, i. m., 388, 505.

${ }^{54}$ Szilágyi Márton idézett monográfiájában kimutatta, hogy az Uránia egyes közleményei megtalálták az utat a korabeli kalendáriumok világába.

${ }^{55}$ A folyóiratok programjairól részletesen lásd Debreczeni Attila, Tudós hazafiak és érzékeny emberek, Bp., Universitas, 2009, 175-195, 371-405.
} 
Lám! nem igaz, hogy ama’ tehetetlen gyermeki korból

Felserdült virgontz Ifjú ne szeretne leszálni

Váz-paripájáról [...]

Léptsőnn lépeget e’ nemesebb tzélokra teremtett

Állat, az oktalanok közzül, nagy hívatal[á]hoz

Illő póltza felé.

A tudományok általi megvilágosodás gyermekkor-felnőttkor metaforikája az e tudás eredetéről és céljáról vallott szemlélet kereteibe illeszkedik: az ember megvilágosodása végső soron az isteni cél beteljesítése, melynek így hirdeti dicsőségét. E gondolat vezeti be az Esmérkedés az égitestekkel címü közlemény fejtegetéseit, immár értekező nyelven, de egyértelmű allúziókkal: „Ezek a kérdések [ti. a véghetetlen Mindenségre vonatkozók] azóta támadtak, miólta az emberi nemzet gyermeki korából kikelvén, és lelki tehetségei kijjebb-kijjebb fejtődzvén, ráesmert magára, hogy e főldön lévő minden állatok felett ő az, kit a Teremtő ide rendelt, felséges munkáinak vizsgálására, megítélésére és csudállására, hogy ezek által megszenteltessék az Ö neve." ${ }^{" 56} \mathrm{~A}$ tudományok a fiziko-teológiai szemlélet kereteibe illeszkedve nyerik el végső értelmüket, $s$ válnak a megvilágosodott ember megkülönböztető jegyévé, s ugyancsak e szemléletmóddal függ össze az így felfogott tudományok minél szélesebb körben való terjesztésére irányuló törekvés is.

Fiziko-teológia, tudomány, poézis

A fiziko-teológiát és a fiziko-teológiai irodalmat alapvető munkák sora tárgyalta már, ${ }^{57}$ általában valamely szerző (Csokonai, Szőnyi Benjámin) életműve felől exponálva a kérdéskört. Fazekast rendszerint szórványosan, elsősorban egy-egy költeménye kapcsán említik, ezzel szemben Vörös Imre monográfiája számos helyen és vonatkozásban hivatkozik Fazekas műveire, de mivel a természetszemlélet általános kérdéseinek szempontjából vet számot a fiziko-teológiával, a Fazekasra vonatkozó nagyon fontos megfigyelések, utalások szükségszerüen széttagolódnak. Feltételezésünk szerint a fiziko-teológia Fazekas életmüvének konstans és meghatározó szemléleti magját és alkotói módszerét képezi, s mint ilyen, kitüntetett jelentöséggel bír a lehetséges értelmezési keretek kialakitása során.

A Kalendáriom programszövegeiben a fiziko-teológiai szemlélet három jellegzetes elemének érvényesülését is megfigyelhettük. A tudományokat az isteni gondviselés nagy tervének részeként azonosíthattuk, hiszen az ember arra teremtetett, hogy az

\footnotetext{
${ }^{56}$ FMÖM II. 66.

${ }^{57}$ SzAuder József, Az estve és Az álom keletkezése = Sz. J., Az éj és a csillagok, Bp., Akadémiai, 1980, 241-292; VöRös Imre, Természetszemlélet a felvilágosodás kori magyar irodalomban, Bp., Akadémiai, 1991; IMre Mihály, Vesztett csata a fiziko-teologizmus örökségével = Szönyi Benjámin és kora, szerk. IMRE Mihály, Hódmezővásárhely, Református Gimnázium, 1997, valamint Bíró, i. m. A fiziko-teologiát Fazekas kapcsán többször megemlíti Julow Viktor is.
} 
őt körülvevő világot megismerje, $s$ benne felismerje az isteni gondviselés nagyszerűségét. A tudományok így felfogott eredetük és végső céljuk mellett alapvetően kettős rendeltetéssel bírnak, egyrészt a természet szakszerü (szaktudományos) megismerésével szolgálniuk kell a világosság terjesztését a babonaság ellenében, másrészt és épp ezért ki kell lépniük a szigorúan vett szaktudományosság köréből, hogy az ismeretek szélesebb kör számára hozzáférhetővé válhassanak. A Kalendáriom e hármas küldetés felvállalásában megegyezik a hazai fiziko-teológiai irodalom jeles darabjaival, olyanokkal, mint Szőnyi Benjámin Gyermekek fisikája, Segesvári István Derhamfordítása, Szentgyörgyi József Legnevezetesebb természeti dolgok esmérete címü könyve vagy Diószegi Sámuel prédikációi és más kéziratos prédikációk. Az említhető művek köréből azért is emeltük ki épp ezeket, mert debreceni illetőségü szerzőkről van szó (köztük Szentgyörgyi személyében Fazekassal vélhetően közeli kapcsolatokat ápoló kortársról, Diószegi személyében pedig szerzőtársáról, sógoráról), hangsúlyozandó a debreceni kollégium szellemi közegének jelentőségét a hazai fiziko-teologizmust illetően. ${ }^{58} \mathrm{~A}$ müvek maguk gyakran kimondottan tankönyvnek készültek, de legalábbis nem pusztán tudós olvasóközönség számára. A szigorú tudományosság követelményeinek többnyire úgy tettek eleget, hogy a közérthetöségre törekvő kifejtést nagy és részletes jegyzetanyaggal, hivatkozásokkal vették körül.

Fazekas és sógora, Diószegi Sámuel az 1807-ben megjelent Magyar Füvész Könyvben is e hármas küldetésnek kívánt megfelelni. A mottó a bibliából való („Nézzétek meg a’ mezei VIRÁGOKAT. / Pompásabbak azok Salamonnál. Mát VI.”), s a megmaradt példányokról írott 1823-as jelentésében is elsőként említi Fazekas a fizikoteológiai érvet a munka elkészítésének indokai között: „A természet bölcs teremtője és fenntartója [...] szent nevét, csudállatos munkáinak közelebbről való vizsgáltatásával, és esmértetésével igyekeztünk dicsőittetni”. Majd az esmértetés kifejtéseként utal arra, hogy munkájukat 'oskolai' használatra szánták, s következő jelentésében kéri, hogy a sok-sok megmaradt példány „arra a helyre tétetődjön, mellyre általunk is rendeltetett, azaz a tanuló ifuúság számára" ${ }^{59} \mathrm{~A}$ vizsgáltatás és esmértetés kettőssége a Füvész Könyv Elöljáró Beszédében is megjelenik, ${ }^{60}$ mert egyrészt szempontként fogalmaztatik meg a 'világos és tömör, nem unalmas és homályos' előadásmód, hogy 'a könyvnek akárki azonnal hasznát vehesse', másrészt pedig 'hazánk természeti-tudományokban jártas túdós férjifiainak' szakmai elvárásait is teljesíteni kívánja a munka, hiszen az előljáró beszéd számot ad a fő forrásmunkákról és a feldolgozás módjáról, a részletes jegyzetek pedig szakszerűen hivatkoznak és magyaráznak. A könyv újdonságát 'a két hazában' a botránkoztató, babonás elnevezéseket tartalmazó kuruzsló

\footnotetext{
${ }^{58}$ Lásd erről Szauder, i. m., 259; ImRe, i. m., 172. A kéziratos prédikációkra Imre Mihály hívta fel figyelmemet.

${ }^{59}$ FMÖM II. 120. és 122.

${ }^{60}$ Megjelennek e célok a Füvészkönyv készítéséről hírt adó két aprónyomtatványban, a Jelentésben és a Toldalékban is, melyeket Julow Viktor fedezett fel és adott ki a Déri Múzeum 1962-1964-es évekre szóló évkönyvében (Debrecen, 1965, 397-414).
} 
célú füveskönyvek ellenében határozzák meg: maguk is az orvosi felhasználás regisztrálásával kezdtek munkához, de erről lemondtak, mert „kétféle tudományt összezavarni mindenkor káros". A Magyar Füvész Könyv tehát tudomány-koncepciójában lényegében azonos a Kalendáriuméval, a különbséget, mint azt Fazekas maga hangsúlyozta, a választott müfaj jelenti, s közülük az utóbbit ítéli hatékonyabbnak a feltett célok megvalósításában.

A Kalendáriom a csillagászat, a Füvész Könyv a botanika tudományának eredményeit közvetíti, vagyis a fiziko-teológiai természetkép három nagy tartománya közül kettő vizsgálatára irányul. ${ }^{61} \mathrm{~A}$ tudományok önmagukban ugyanúgy gyönyörüséget okoznak (az utóbbi előljáró beszéde szerint), ahogy gyönyörűségét leli a 'mezei ember' az égbolt és a 'kertész' a virágai szemlélésében, s mint gyönyörüséget okoz az e szemlélet jegyében fogant poézis. Imre Mihály Szőnyi Benjámin kapcsán fogalmaz általános érvénnyel: „A fiziko-teologizmus műveinek többségéhez híven Szőnyit is leginkább a mikro- és makrovilág bűvöli el. Leírásaiban mindig visszatérő fordulat a szemléleten túl a csodálat és elragadtatás többletérzése." ${ }^{2}$ Fazekas költészetében ugyancsak kiemelt tematikus vonulatot jelent a végtelen kozmosz és a kert kisvilága. Az előbbire példa az Egy férje elestén kesergö özvegy, A kétségbeesett szerelem, s némiképp $A z$ öröm tündérsége és a Cs. et $F$. is, valamint a Kalendáriomban az Esmérkedés az égitestekkel után függesztett disztichonok, melyek Egy astronomiai értekezés után címmel szerepelnek a kiadásokban. A newtoni világkép 'szakadhatatlan vonszódás' által összetartott és a 'manus emendatrix ${ }^{63}$ jóindulatára utalt 'nagy Minden'-e tünik elénk a költeményekből. A szemlélése által kiváltott fenséges elragadtatottság a versekben ugyanakkor rendre a látomás puszta álomképpé válásával ellenpontozódik ironikusan.

A fiziko-teológiai szemlélettől ugyancsak mélyen áthatott a kert toposza Fazekas költészetében. Legkifejtettebb példája ennek a más vonatkozásban már idézett $A z$ én kis kertem, melyben a természet csodálatos célszerüsége fölött érzett elragadtatottság közvetlenül áttűnik az isteni gondviselés dicséretébe:

$$
\begin{aligned}
& \text { Jer örvendezvén az egekkel } \\
& \text { Együnk és igyunk víg lélekkel } \\
& \text { Áldván a' természet jó attyát } \\
& \text { Ki táplálja minden állattját } \\
& \text { Ki a' láthatatlan párából } \\
& \text { 'S sok ezernyi szerek langjából } \\
& \text { Felhőt hirdet a' levegőbe, } \\
& \text { 'S essőt ád alkalmas időbe. }
\end{aligned}
$$

\footnotetext{
${ }^{61}$ Vörös, i. m., 73. (A harmadik tartomány az állatvilág.)

${ }^{62}$ IMRE, i. m., 145.

${ }^{63}$ Bíró, i. m., 377.
} 
A természet apró gyönyörűségeinek mikrovilága tűnik elénk Az én kis kertem jelentős részében, valamint $A^{\prime}$ tavasz eleje prózájában és betétverseiben. A fiziko-teológiai frazeológia meghatározóan formálja a Nyári esti dal világát is, amely szemléletesen mutatja, hogy a fiziko-teológiai leíró technika és eszköztár milyen nagy mértékben meghatározta Fazekas verseit, hiszen e költemény szerkezete a keretversszakok közötti három szakaszban a természet három nagy tartományának leírására épül. ${ }^{64}$ Fazekas egy másik jelentös verse, a [Mint mikor a nap...] a fiziko-teológiai alkonyleírások fényeket és végtelen perspektívát használó típusának eszközeiböl építkezik, ${ }^{65}$ akárcsak az Éljen a barátság! címü költemény eleje. A fiziko-teologizmus egyik centrális szemléleti eleme, az emberérdekü célszerűség gondolata hatja át $A z$ öröm tündérsége nevezetes sorait:

$$
\begin{aligned}
& \text { Álmélkodva néztem e’ nagy játék szinbe } \\
& \text { Hogy a' bölts természet mennyi féle szinbe } \\
& \text { Hordja fel játékát a' néző elébe } \\
& \text { 's Hány féle hangokkal zengedez fülébe. } \\
& \text { Nemem méltóságát egésszen érzettem } \\
& \text { Látvánn hogy e’ mind ő érte van, 's érettem } \\
& \text { Érzém mely nagy lelkem állat társim felett } \\
& \text { Kikbe íly böltset a' fö bölts nem lehellett. }
\end{aligned}
$$

Az emberérdekű célszerüség szorosan összefonódik az ember mint a földi létezők legnemesebbike gondolatával, amint azt az idézet utolsó két sorában látjuk. E belátás alapozta meg, mint arról az elöző alfejezet végén szó volt, a fiziko-teológiai tudományfelfogást, $s$ e belátás képezi a poézisfelfogás alapját is, mikor a Dorottya-levelekben az 'erkölcsi rajzolat' hiánya kéretik számon a vígeposzíró Csokonain: „Az ember lerajzolásán nem az emberi képnek és testállásnak leirását értem, hanem annak előadását, ami az embert az Istennek e földön lévő minden teremtései közt legnemesebbé tészi; [...] őnéki hát a lelke körül kell kereskedni." A poéta feladata ennek megfelelően határoztatik meg: „Akármicsoda tarka névvel bérmálják is el az Urak versezeteiket, csak az annak a lelke, hogy eleven szinü és szép hangzatú erkölcs légyen benne, és tessen a léleknek." ${ }^{\prime 6} \mathrm{Az}$ általunk kiemelt rész jól felismerhetően a horatiusi utile et dulce elvét fogalmazza meg a poétával szembeni fő követelményként.

\footnotetext{
${ }^{64}$ VöRös, i. m., 119, 163.

${ }^{65}$ Uo., 59. Szintén utal a fiziko-teológiára a vers önálló elemzése (GöRöMBEI András, Fazekas Mihály: Mint mikor a nap, ItK, 1969/2-3, 274-281.), melyet Julow Viktor monográfiája is követ.

${ }^{66}$ FMÖM II. 21. és 15.
} 
Használni és gyönyörködtetni

A feltehetőleg Fazekas által írott apokrif Dorottya-levelek ${ }^{67}$ a szakirodalomban Julow Viktor óta a Lúdas Matyi megszületése kapcsán kerülnek említésre: a levelekben megfogalmazott poétikai elvek a Dorottyával szembeni kifogásokat alapozzák meg, a Lúdas Matyi pedig azok megvalósulását illusztrálja, így a Lúdas Matyi a Dorottyával való játékosan komoly versengésként áll előttünk. A filológiai konstrukció nagy meggyőző erővel bír, de hogy valóban egy ilyen versengésből született-e a mű, annak bizonyítására tényleges adat nem áll rendelkezésre. Ha tehát ez filológiailag megalapozott keletkezéstörténetként nem is olvasható, annyi azért kijelenthető, hogy a szóba hozott szövegek a Lúdas Matyi releváns kontextusát jelentik, ráadásul ugyanabban az időkörben. A bennük megfogalmazott poétikai elvek ugyanis érvényes szempontot kínálnak a mü értelmezéséhez, hiszen Fazekas egyetlen kifejtettebb poétikai megnyilatkozása a Lúdas Matyi példázatára közvetlenül vonatkoztatható („A lélek a poétától azt kívánja, hogy állítsa elébe a virtust és a vétket" ${ }^{\prime 6}$ ).

A Dorottya-levelek poézisfelfogása ugyanakkor nem csak és nem elsősorban a Lúdas Matyi összefüggésében releváns. Az eleven szinü és szép hangzatú erkölcs kívánalma az erkölcsnemesítés funkciójában mutatja fel a horatiusi használni és gyönyörködtetni maxima jelentését a poézis egészére érvényesen, meglehetős általánosságban. Kontextualizálásához a Dorottya-levelek egy másik, két bekezdéssel későbbi szöveghelye jelenthet támpontot: „Amelly versezetnek nem az erkölcs a főcélja, nincsen annak lelke, akármillyen szépnek tessék is különben: hasonlatos az a festett képhez és a pengö hegedühöz, mellyek az érzékenységeket felcsiklándozzák, de a sziv kivánságait ki nem elégitik." ${ }^{39}$ Mint Szilágyi Márton rámutatott, a szövegrész bibliai allúzióra épül (1Kor, 13,1), amely „még inkább kiemeli a mondat morálteológiai alapozottságát, különösen, hogy az idézet éppen a Szent Pál-i gondolat központi fogalmát, a szeretetet nem veszi át szó szerint, s így a hiányával, azaz egy elliptikus szerkezet révén lépteti be a fiktív levélbe"70 A morálteológiai kontextus meghatározó voltát, úgy véljük, további vonatkozások is erősítik.

A festett kép és pengő hegedü (a bibliai textusban 'pengő czimbalom') közvetlenül a gondolatmenetet elindító szembeállítás összefüggésében értelmezhető, amely

\footnotetext{
${ }^{67}$ Újabban Borbély Szilárd megkérdőjelezte Fazekas szerzőségét, alapvetően Julow Viktor bizonyításának elégtelenségei miatt (BorbéLY, i. m., 182.). A kritikai kiadásban felsorolt több mint húsz érv nagy része valóban kétes értékü, de kettő akkor is figyelmet érdemel (FMÖM II. 215-217). Az egyik az Irodalomtörténeti Közlemények szerkesztőjének megjegyzése Fazekas szerzőségére vonatkozóan a szöveg első közlésekor, noha nem tudjuk, jegyzését mire alapozta. A másik s valóban perdöntő filológiai adat a Debreceni Irodalmi Múzeumban lévő kéziraton található utólagos javítások autográf jellege: megítélésünk szerint ezek a javítások valóban származhatnak Fazekas kezétől, s valószínű, hogy tőle származnak. A bizonytalansági tényezőt az jelenti, hogy a javítások mennyisége csekély, s jobbára szavak korrekciójára terjed ki, így a kézírás megítélése csak kis és töredékes korpusz alapján történhet, ami teljes egyértelműséget nem tesz lehetővé. Mindezek alapján a feltehetően Fazekas müve minősítést látjuk indokoltnak. ${ }^{68}$ FMÖM II. 15.

${ }^{69} \mathrm{Uo}$.

${ }^{70}$ SZILÁGyi, Határpontok, i. m., 166.
} 
a képfestést és muzsikát veti össze a poézissel, megállapítván, hogy az előbbiek minden tökéletességük mellett sem vetekedhetnek az utóbbival, mert csak érzéki hatást keltenek, míg a poézis az érzéki hatást magasabb célra használja: „Ez a két tehetség [ti. a festés és hangicsálás] a poétában is megkívántatik, mert ezek nélkül munkája kietlen, hanem ezek az ő kezébe csak eszközök föcéljának elérésére." ${ }^{\prime 11}$ A képfestés és muzsika poézissel szemben alárendelt volta a református hagyomány szemléletét látszik tükrözni (képellenesség, az ének zenei kíséretének tilalma versus a kimondott szó elsőbbsége). A 'hegedü' motívuma azonban egy konkrét szövegösszefüggésben is szemlélhetö, amely ugyancsak bibliai textusra vezethetö vissza. Az én poézisom hangszerkatalógusában a hegedủ az 1. sorban a lant és a tárogató mellett szerepel, némiképp szokatlanul, hiszen a cigányzenészek hangszere leginkább a duhaj mulatozások képzetét idézte meg a korban. Itt azonban már csak azért sem szerepelhet ilyen értelemben, mert a 4. sorban a doromb képviseli az alantasabb használati módot, eltérve az első sorban említett hangszerektől.

A hegedü itteni említésekor sokkal inkább a református énekköltészetre gondolhatunk háttérhagyományként. Szőnyi Benjámin nagyon sok kiadást megért énekeskönyve, mely címlapján a Jelenések könyvének két helyére (5:8-9., 14:2-3.) hivatkozik, a Szentek hegedüje címet viselte. A Károli-féle bibliafordítás a 'hárfa' helyett 'hegedüt' mond a hivatkozott helyeken, miként a Zsoltárok könyvében is. ${ }^{72}$ A 49. zsoltár eleje Szenci Molnár Albert fordításában így szól: „Az én szájam szól nagy bölcsességet, / Es elmém gondol jo értelmeket, / Ez példára magamis figyelmezec, / Hegedö szóban szép mesét jelentec."73 E szöveghelyre utal Csokonai a Dayka verseiről írott bírálatában, éppen egy vers poétikai karakterét meghatározva: „az egész Dalt nem festői, hanem példázó és ábrázoló Darabnak ítélném, a' mellyben a’ Poéta, hogy ama' Sz: Lyricussal szóljak, hegedüszóban Szép mesét jelentett". ${ }^{74}$ Nem tudjuk filológiai adattal igazolni, hogy Fazekas ismerte Szőnyi vagy Csokonai művét, s azt sem, hogy Az én poézisom című Fazekas-versben a hegedü e hagyományra utal, arra viszont van adatunk, hogy e protestáns zsoltár- és énekhagyomány szellemében idézte meg maga is a 'szent lyrikust', a zsoltáríró Dávid királyt a Kalendáriom egyik cikkében, a 104. zsoltárra hivatkozva. ${ }^{75}$

A hegedü tehát a horatiusi használni és gyönyörködtetni elv példája és ellenpéldája is egyben az idézett szövegekben, bibliai textustól és kontextustól függően. A szép

\footnotetext{
${ }^{71}$ FMÖM II. 15.

${ }^{72}$ Lásd például Pethe Ferenc 1794-es utrechti kiadását (229, 234). Minderről részletesen szól Fekete Csaba tanulmánya: Szőnyi Benjámin és a magyar református himnológia = Szőnyi Benjámin és kora, $i$. m., 36-38.

${ }^{73}$ Szenci Molnár Albert költői müvei, kiad. Stoll Béla, Bp., Akadémiai, 1971, 125. (Pethe bibliakiadásában: 29.)

${ }^{74}$ Csokonai Vitéz Mihály Összes Müvei, Tanulmányok, s. a. r. Borbély Szilárd, Debreczeni Attila, Orosz Beáta, Bp., Akadémai, 2002, 60.

${ }^{75}$ FMÖM II. 67-68.
} 
hangzatú erkölcs kívánalma egészen a 'hegedűszóban szép mesét jelentő' 'szent lyrikus' szellemét tükrözi, ami egybehangzik a Lúdas Matyi példázatának morálteológiai alapozottságával éppúgy, mint a tudományok és a poézis kapcsán említett fiziko-teológiai összefüggésekkel. A már többször szóba hozott Szőnyi Benjámin fiziko-teológiai művét, a Szentek hegedüjét Kecskés András „szépirodalmi igénnyel megfogalmazott alkalmazott költészetnek" nevezi, ${ }^{76} \mathrm{~s}$ ezt egyetértőleg idézi Imre Mihály is, mikor Szőnyi életművét a 'zsoltárköltészet hagyományrendszerén' belül, annak 'terjedelmes epilógusaként' értelmezi. ${ }^{77}$ Ovatosan, de némi határozottsággal fogalmazzuk meg az ezen értelmezésekhez kötődő hipotézist, amely eddigi gondolatmenetünkből következik: a Fazekas életművét egybefogó fiziko-teológiai szemléletmód keretei között a horatiusi utile et dulce olyan felfogása volt érvényben a poézisre nézve, amely leginkább e hagyományrendszer örököseként tűnik értelmezhetőnek.

Amikor viszont a Kalendáriomra nézve az a cél fogalmazódik meg az 1826-os rövid programcikkben, hogy az égitestekről szóló eddigi írások helyett „más, részszerént gyönyörködtetö, részszerént szükséges és hasznos dolgokkal fogjuk Kalendáriumunkat bővíteni", akkor az nem pusztán az egyes írások funkciójának megoszlásaként olvasható (az eddigiek szellemében), hanem az írások megoszlásaként is (vannak hasznosak és vannak gyönyörködtetőek). Ez utóbbi olvasásmód már csak azért is indokolt, mert a Kalendáriom anyaga, mint láttuk, valóban mutat ilyen megoszlást, ami szoros kapcsolatban van a hasznosság Julow Viktor által kiemelt prakticista értelmezésével. S ha a Lúdas Matyira gondolunk, a paratextusokban megfogalmazódó példázat és a fabuláris szint között nagyra nyílt távolság is inkább érthető 'használni és gyönyörködtetni' egymásmellettiségeként, ahol a hasznosság persze az erkölcsi tanító szándék elvi dominanciáját jelenti továbbra is. A pálya végi nagy összegző versben pedig a hasznosságnak egy további összefüggése jelenik meg, amely szolgálatként értelmezi azt.

\section{Önértelmezés \\ (A Kalendáriom magyarázatja után serkent gondolatok számvetése)}

\section{Extenuatio és hypocrisis}

Julow Viktor monográfiáját a Kalendáriom magyarázatja után serkent gondolatok című versről írott meghatott sorok zárják, 'Arany János őszikéivel rokon számvetésként' jellemezve azt. ${ }^{78} \mathrm{Az}$ analógia indokoltnak látszik például az Epilógus

\footnotetext{
${ }^{76}$ KeCsKés András, Szőnyi Benjámin énekszövegeinek ritmikája = Szönyi Benjámin és kora, i. m., 70.

${ }^{77}$ IMRE, i. m., 167.

${ }^{78}$ Julow, Fazekas Mihály, i. m., 451-453. A vers „elégikus-sztoikus modalitását” kiemelte már SzegedyMaszák Mihály is: A magyar költészet föbb típusai a kései XVIII. és a korai XIX. században = Sz. M. M., Világkép és stílus, Bp., Magvető, 1980, 50.
} 
önjellemzésével és hangnemével való hasonlóság alapján, ${ }^{79}$ de ebből számunkra az is következik, hogy Fazekas költeményét szintén megformált önképként, nem pusztán életrajzi dokumentumként kell olvasnunk. A cím némileg talányos, nem tudjuk, milyen ihletet adó 'magyarázatra' utal. ${ }^{80} \mathrm{~A}$ vers alapötlete mindenesetre az, hogy miként Gergely pápa naptárreformjának bevezetésekor elvesztek napok, úgy a saját életpályának is voltak elveszett időszakai, melyek nem szolgáltak a haza hasznára. Az ezt kifejtő első két versszak után a következő kettő a használni törekvő szándék állandó meglétét hangsúlyozza, a következő három számot vet a haza javára végzettekkel (katonáskodás, poézis, botanika, csillagászat), a záró szakasz pedig a húsvétra való utalással már egy másik életre tekint. ${ }^{81}$

A költeményt verstani alkata $(8 a+7 b+8 a+7 b+7 c+7 c)$ meditatívvá alakítja, ahogy a szakaszok utolsó, páros rímű sorai szentenciaszerüen meglassulnak. Az ismétlödések ezeknek némi refrénszerüséget kölcsönöznek, a 3-7. versszakok zárósoraiban ugyanis az ötből négyszer fordul elő a 'tehettem' szó (elöször 'valamiröl', majd háromszor 'valamit' vonzattal), s mindannyiszor tagadó vagy korlátozó értelemben, a versegységeket záró pozícióban (a 4. és a 7. szakaszban) azonosan. A rímhívószóként, szinte refrénszerüen ismételt 'többet nem tehettem', illetve 'ennyit is tehettem' kijelentés a szintén visszatérően (négyszer) ismételt 'használni' ige jelentéskörében nyeri el értelmét, mellyel az ugyanennyiszer szereplö 'haza' három helyen egy nyelvtani szerkezetben áll. A vers szövegösszefüggései alapján tehát a hasznosság itt nem 'az egész pályát jellemző gyakorlatias segíteni akarást, prakticizmust' jelenti, s nem értelmezhető a használni és gyönyörködtetni poétikai elve szerint sem, sokkal inkább a haza javára végzett szolgálatként érthető, a tudós hazafiság beszédmódjának szakrális mintázatot követő toposza és a szolgálat református hagyományban adott kontextusa szerint.

Az alaphangoltságot a meg nem elégedettség rezignációja jelenti, amely a szándékok és tettek között érzékelt jelentékeny távolságból fakad. Először önvádként hangzik el a haszon nélkül elvesztegetett sok év miatti panasz („Ha éltemen végignézek, / Csak elijjedek tőle / Magam is, hogy mennyi tízek / Esnének ki belőle, / Mellyek e jó hazának / Hasznára nem valának"). A panaszra a szándék megléte és valóra váltásának törekvései hoznak vigasztalást („De tudtam mindég érzeni, / Hogy kellene igazán

\footnotetext{
${ }^{79}$ Példaként említhető különösen a pálya egészére vonatkozó rezignált meg nem elégedettség („Mily temérdek munka várt még!... / Mily kevés az, mit beválték / félbe-szerbe’”), a 'kevély fogat és az út szélén baktató ellentéte, amely csendes, szerény önérzetet nyilvánít meg („az útfélen itt-ott / Egy kis virág nekem nyitott: / Azt leszedve / megvolt szívem minden kedve."). Arany János Munkái, Kisebb költemények 3. 1860-1882, s. a. r. S. VARGA Pál, Bp., Universitas, 2019, 204-206.

${ }^{80}$ A vers Lovász Imre kiadásában maradt fenn, hitelességét az életmü ismert vonatkozásaival való közvetlen megfelelései és az 'aranyszám' szövegpárhuzama alapján bizonyíthatónak tekintjük. Olyan elöszöveget azonban, amelyre a cím alapján a szöveg utalna, nem ismerünk.

${ }^{81} \mathrm{Az}$ itt említett 'aranyszám' ugyanis húsvét napjának kiszámítási módja (évszám+1 osztva tizenkilenccel maradéka), amit disztichonokba is foglalt (FMÖM I. 270; FMÖM II. 87.), a vers hitelessége mellett ez a szövegösszefüggés az egyik fö filológiai adat. A versszakban ez alapján nyilvánvalóan nem a lélekvándorlásról van szó, mint Julow Viktor véli.
} 
/ És haszonnal segíteni / E’ bajban forgó hazán [...] Használtam is, megesmérem, / Mikor hogy tőlt, ha kellett"). A tettekkel való számvetés során előbb a katonai pályát említi, ez az egyetlen hely a versben, ahol a valódi megelégedés hangja szól („Hogy ennyit is tehettem, / Boldogságom érzettem”), majd a poézisre, botanikára, csillagászatra utal, elégedetlen elégedettséggel, csekélységnek látván az eredményeket. A tudós hazafiság beszédmódjának metaforikája szerint értett 'haza óltárán benyújtott áldozat' az 'ökrökkel, bakokkal' szemben csupán 'egy-két virág' és az 'oltárra festett csillag', a nyelvet pedig 'lant' helyett 'duda' dicséri. A költemény számvetése egészében az extenuatio ${ }^{82}$ alakzatára épül, amikor is az önkicsinyítés mint a túlzás formája válik a visszatekintő meg nem elégedett rezignáció hordozójává.

A tetteket számba vevő versszakokban új vonatkozást jelent, hogy azok nemcsak a szándékhoz viszonyítva ítéltetnek meg, hanem mások tetteihez képest is. A poézist megidéző versszakot három elemből álló ellentét formálja meg:

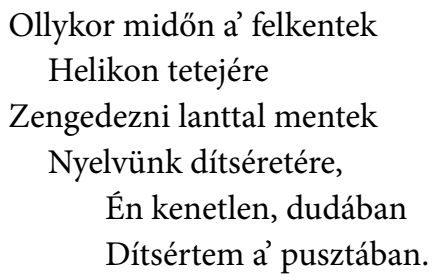

A 'Helikon, lant, felkentek'-'puszta, duda, kenetlen' kettősségében egyszerre érvényesül a külső és a saját nézőpontból adódó minősités: a beavatott 'felkentek' világa felől nézve a 'kenetlen' profanus kivülállóként jelenik meg már a puszta megnevezés által, ugyanakkor az 'Én kenetlen' nem pusztán megnevezés, de e pozíció felvállalása is egyben. Annak jelzése, hogy a 'felkent-kenetlen' szópár nem az egyetlen lehetséges értelmezési mező, vagyis ami e mezőben szemlélve egyértelmű értékminősítést nyer, más nézőpontból másként is értékelhető. Mert más nézőpontból maga a 'felkentség' kerül idézőjelbe azáltal, hogy ironikusan inadekvát szembeállításban használtatik. A 'felkent' ellentétpárja a 'profánus, laikus, be nem avatot', a 'kenetlen' ilyen értelemben a korban nem használatos, ugyanakkor nyelvtanilag logikus alak. Jelentése pedig egy másik szinten épít ki ellentétet azáltal, hogy a nyikorgó szekérkereket idézi meg, de már aligha komolyan vehetően, inkább játékos iróniával. Ez a relativizáló kettősség vetül ki a 'felkentek Helikonjának' mint a poézis egyetlen lehetséges helyének és a 'pusztának' mint mégis lehetséges másik helynek az ellentétébe. Az önértés lényegét tekintve tehát az 'Én kenetlen' nem kívül áll a poézis felkentjeinek világán, hanem ahhoz képest máshol. Ami a felkentek világának nézőpontját elfogadva extenuatiónak

\footnotetext{
${ }^{82}$ Az extenuatio alakzatának figyelembevételét Fazakas Gergely Tamás javasolta Az én poézisom értelmezése kapcsán, s ehhez kötődik Bódi Katalin ugyancsak inspiráló észrevétele: felvetéseik továbbgondolása jelentős mértékben alakította a dolgozat koncepcióját.
} 
látszik, e másik nézőpontból a hypocrisis ${ }^{83}$ alakzataként érthető inkább, a megvont mérlegből kibontakozó önkép tehát sajátos kettősséget mutat, egyrészt rezignált önkicsinyítés, másrészt az önérték tudata hatja át.

E kettősség, a másik nézőpont megjelenik a 'lant' és a 'duda' szembeállításában is, a motivikus ellentét harmadik elemeként, az életmű sajátos konkordanciahálójának részeként. A Lúdas Matyi 1817-es szerzői előszava a világra bocsátandó művet a dudaszóra táncoló medvéhez hasonlítja, míg a költeményekben ${ }^{84}$ a lant általában a költői megszólalásmód attribútuma a kor szokásrendje szerint. Az én poézisom elején, az Aprótseprőségek jellemzésével kapcsolatos állásfoglalás elhárításakor a 'lant, hegedü, tárogató-doromb' hangszerkatalógust láttuk feltűnni. Mivel a „dorombot ekkoriban a lant, vagyis a komoly, fennkölt líra ellentétpárjaként, 'negatív lant'-ként emlegették", ${ }^{85}$ az ellentét itt is kiépülni látszik. A 4. sor megfogalmazása ugyanakkor ezt rögtön vissza is metszi: „És ha dorombba verik sem szégyenlik magokat meg [a firkált aprótseprőségek]”. Nem az első pillantásra kézenfekvő ellentét hangsúlyozódik tehát, hanem a megengedő jelleg: ami egyfelől egyértelműen alantasnak tủnik, másfelöl nézve az sem feltétlenül szégyellni való. Továbbá az Aprótsepröségek címében és ajánlásában feltűnő szerénység-toposz ebben az összefüggésben ugyanolyan kétértelmüséget hordoz, mint $A z$ én poézisom és a pálya végi összegző vers. A nyilvánosság elé lépni szándékozó szerző beszédpozíciója, ahogy ezt a Kajánhoz szóló ajánlás elbizonytalanító kettőssége jelzi, egyszerre nyilvánítja meg a külső és belső nézőpontot saját poézise megítélésében, így egyszerre értelmezhető az extenuatio és a hypocrysis alakzataként.

A késői visszatekintő-összegző költemény tehát egy szemléleti-motivikus szöveghálóba szövődve reflektál saját pozíciójára. Ugyanakkor nem tagadhatóak a költemény referenciális elemei sem, hiszen a katonáskodás, a sebesülés megidézése, a Füvész Könyvre és a Kalendáriomra való utalások mind eléggé egyértelműek. Ebben a sorban a poézis megidézése kapcsán a 'felkentek' említése tekinthető referenciális utalásként, Julow Viktor is így értette, Kazinczyra vonatkoztatva. Valóban, Kazinczy magát a gráciák felkent papjaként jelenítette meg a nyilvánosság előtt és leveleiben pályája során mindvégig, részben szabadkőmüves szerepértelmezése szerint ${ }^{86}$ továbbá ismeretes Kazinczy és Fazekas szembekerülése az Árkádia-perben, a versbéli utalás így joggal vonatkoztatható Kazinczyra. Viszonyuk és a per áttekintése nem

\footnotetext{
${ }^{83} \mathrm{Az}$ 'elleplezés retorikájának' használata régről jól ismert eljárás, Imre Mihály Szenci Molnár Albert Psaltériumának ajánlásában mutatja ki és értelmezi a hypocrisis retorikai alakzatát. IMRE Mihály, „Úton járásnak megírása”: Kulturális emlékezet, retorikai-poétikai elvek érvényesülése Szenci Molnár Albert müveiben, Bp., Balassi 2009, 251-252.

${ }^{84}$ Lásd például az Ama nemzetek... kezdetü, a Domokos Lajos halálára írott és az Éljen a barátság! címü verseket.

${ }^{85}$ Csörsz Rumen István bevezetője a Doromb: Költészettörténeti tanulmányok című sorozat első számához (Bp., reciti, 2012, 7.).

${ }^{86}$ Lásd részletesen Gergye, i. m., 14-42; Debreczeni, Tudós hazafiak, i. m., 380-388.
} 
lehet itt feladatunk (erről más helyütt amúgy is részletesen szóltunk ${ }^{87}$ ), most csak azt a vonatkozást emeljük ki, amely a fentebb mondottakkal a legszorosabb kapcsolatban látszik lenni. Úgy tünik, hogy a per kezdetén, Fazekas Kazinczynak írott 1806. szeptember 23-i levelében lényegében már megjelenik önértelmező pozíciójának jelzett kettőssége, amelyben egyszerre tekint magára az ellenfél és saját nézőpontjából: „Meglehet hogy kissebbnek talál engem nézni a’ Tekintetes Úr, mintsem hogy tudós Correspondentiájára méltóztathatna: de hitesse el, kérem, magával, hogy ámbár a’ Nagy-világ az én kipallérozásomba erántam mostohább vólt is mint a’ Tekintetes Úrhoz, de ha nemes bajvivásra kerülne is köztünk a’ dolog, soha a’ velem való viaskodás betstelenségére nem fog szolgálni." ${ }^{88}$ Önkicsinyítés és önérzet egyszerre szólal meg e sorokban, ahogy az idézett költői szövegekben is. Ugyanakkor e pozíció nem írható le pusztán Kazinczyval való szembenállásként, a személyes konfrontáció általánosabb összefüggésbe illeszkedik, amely talán még akkor is érzékelhetö, ha pusztán néhány adat extrapolációjaként férhetünk hozzá.

\section{A Debreceni Grammatika szemléletének nyomai}

Fazekas a Lúdas Matyi kiadójához, Kerekes Ferenchez írott, 1815. november 24-i levelében így emlékszik vissza a mü keletkezésére: „Matyi az én szülöttem. Született 1804-ben, becsülletet tanulni ment Kazinczy Ferenc úrhoz, ki még akkor nőtelen és magyar vólt". ${ }^{89}$ A mintegy odavetett utolsó megjegyzés, noha szemet szúrt már többeknek, ${ }^{90}$ érdemben nem került kontextusba. Úgy véljük, a 'magyar vólt' a Debreceni Grammatika szóhasználata szerint olvasandó. A mű Elöljáró Beszéde kiemeli, hogy „a Magyarok között, még eddig ugyan, a Köznépnél vagyon a tiszta Magyarság, az ollyan Köznépnél tudniillik, a melly legkevesebb idegen Nemzetűekkel vólt eleitől fogva megelegyedve". ${ }^{11}$ Ezzel a megszorítással élnek a Debreceni Grammatika szerzői akkor is, mikor a tudós társaságot olyan tanult személyekből állítanák fel, „a kik nem tsak született Magyarok, hanem annakfelette Hazánknak ollyan részébenn nevelkedtek 's jutottak ember korra, a mellybenn idegen Nemzetűek, eleitől fogva leg kevesebben lakoztak: mert tsak megengedheti azt akárki, hogy Hazánknak az ollyan részébenn maradt-meg leg tisztábban 's leg épebben a Magyar nyelv". ${ }^{22}$ A hely és a maga eredeti tisztaságában megőrződött magyar nyelv kapcsolata nem pusztán lokalitáson alapul,

\footnotetext{
${ }^{87}$ Lásd Debreczeni, Egy új Fazekas-kiadás, i.m.

${ }^{88}$ KazLev. IV. 321., 997. sz.

${ }^{89}$ FMÖM II. 97.

${ }^{90}$ Bíró, i. m., 375; Julow, Fazekas Mihály, i. m., 322. A kommentárok rendre a 'magyar' szóval foglalkoznak, adottnak véve a 'nőtelen' életrajzi utalását, vagyis hogy ez a Kazinczy 1804. november 11-i házasságkötése előtti időszakot jelöli ki a Lúdas Matyi keletkezési idejéül. Szilágyi Márton a jelen dolgozat kapcsán vetette fel (megjegyzését köszönöm), hogy esetleg e kitétel kapcsolatban lehet a 'magyar' megnevezéssel, amennyiben némi rosszallást fejezhet ki Kazinczy vegyesházassága miatt, vagyis hogy katolikus nőt vett el.

${ }^{91}$ Magyar Grammatika, mellyet készitett Debreczenbenn egy Magyar Társaság, Bécs, 1795, XVII-XVIII.

${ }^{92}$ Uo., XXII.
} 
mert a lokalitás felekezetileg meghatározott: a születés helyére hivatkozó érvelés némileg eufémisztikusan nem mondja ki, hogy a pontos földrajzi megnevezés nélkül hivatkozott hely alatt az aktuális felekezeti dominancia miatt valójában kálvinista értendő. A 'magyar' minősítés tehát a tiszta, eredeti magyarságnak erre a felfogására utal, amely így nem elsőrendüen etnikai, hanem sokkal inkább felekezeti alapozottsággal bír.93

Ismeretes, hogy Kazinczy Debreceni Grammatikával szembeni egyik fö vádpontja, ami már a Domokosékkal folytatott nevezetes 1802-es vita interpretált leírásában is szerepel, az, hogy Dea Debreczen „senkit nem ismér Magyarnak, csak azt, a' ki Debreczenben neveltetett, és ollyan maradt, mint ott volt", ${ }^{34}$ s e gondolat az 1811es Vitkovics-episztolában immár a kálvinistaság elleni fó vádpontként tünik elénk. Minden szempontból elég kézenfekvő arra gondolnunk, hogy Fazekas 1815-ben a Debreceni Grammatika szemléletét és szóhasználatát követi, mikor az 1804-es (egyébként mindvégig rendíthetetlen kálvinista) Kazinczyról azt írja, hogy akkor még magyar volt: az évtizedes vita és szembenállás öltött testet az odavetett megjegyzésben. E hitelesítő, de csak áttételesnek tekinthető kontextus mellett további nyomként egy szövegpárhuzam hozható fel, amely a Debreceni Grammatika idézett részében is megalapozó szerephez jutó 'született Magyar-idegen' ellentétet formulázza. A' tavasz eleje című prózai szöveg, amely ráadásul az Árkádia-per előttről keltezhetô, ${ }^{95}$ kiemelt helyen, a szöveg utolsó bekezdéseként ${ }^{96}$ a következőket fogalmazza meg:

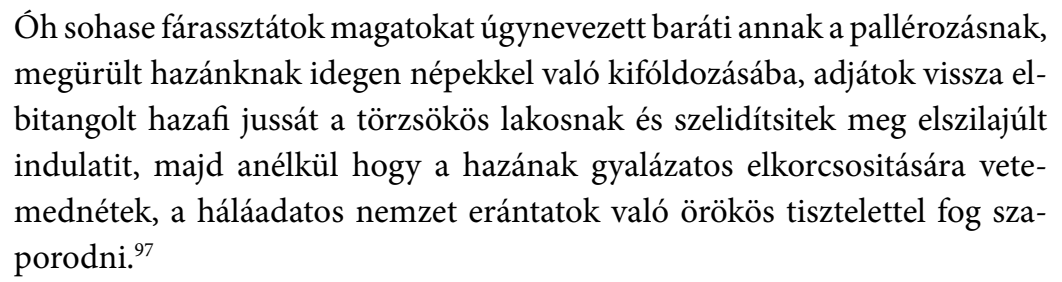

A bekezdést alapvetően az idegen-törzsökös és a pallérozás-korcsosulás ellentétei formálják, melyek szövegösszefüggéseik alapján meglehetős biztonsággal beilleszthetöek korabeli kontextusokba. Az 'idegen-törzsökös' ellentéte az idegen népek betelepítése s a törzsökös lakosok háttérbe szorítása politikai-ideologikus összefüggésére látszik utalni, amely téma a II. József halála utáni első, 1790-es országgyűlést megelözően exponálódott igen élesen a korabeli hírlapokban, folyóiratokban, röpiratokban. Az 'idegen' részben a 'német' eufémisztikus megnevezése volt, részben pedig a sajátidegen oppozíció által erőteljes identitásképző potenciállal rendelkezett, premodern

\footnotetext{
${ }^{93}$ Lásd erről részletesen Debreczeni, Tudós hazafiak, i. m., 348-350; Uő, A debreceniség, i. m.

${ }^{94}$ KazLev. II. 500, 539. sz.

${ }^{95}$ Keltezése bizonytalanul, az Aprótseprőségekhez viszonyítva állapítható meg: 1802-?1804 előtt.

${ }^{96} \mathrm{Nem}$ dönthető el, hogy ez tényleges zárlat-e vagy csak itt maradt abba a szöveg fogalmazása.

${ }^{97}$ FMÖM II. 13.
} 
etnokulturális identitásváltozatként. ${ }^{98}$ Fazekasnak a szakirodalomban sokszor hangoztatott uralkodóhűsége, ragaszkodása a (z egész életművében csak háromszor említett) 'kétfejü sas' szimbólumában ${ }^{99}$ testet öltő identitásváltozathoz mellérendelő viszonyban áll mindezzel, még ha valójában egymás kizáró ellentéteinek tűnnek. S ahogyan ellentétesnek tünnek egy tételezett Debrecen-identitással is, ${ }^{100}$ amelyben a felekezeti fenyegetettség alapvető elemet képez, s mint ilyen, semmiképpen nem Habsburg-párti.

A különböző kontextusokban érvényes érvelések és communitas-eszmék ebben az időszakban különösen virulens módon éltek egymás mellett mindenkinél, tulajdonképpeni szembesítésük nélkül, homogén egyéni identitásváltozatokról így nemigen beszélhetünk. ${ }^{101} \mathrm{Az}$ ideologikus értelmezési mező reflektálatlanul egybefonódott a művelődés kontextusában értett pallérozódás mintakövető jellegével, mely szerint követni kell a nyugati nemzeteket a művelődés útján, s lehetőleg minél többet át kell venni tőlük fordítások által is. Ebből következően az idegen, azaz a német egyik összefüggésben ellenség, a másikban követendő példa volt. Az ideologikus és művelődési kontextus különállását elöször a Debreceni Grammatika előbeszéde hagyta figyelmen kívül, így az ideologikus konstrukció behatolt a művelődési összefüggésekbe. Az idegen-törzsökös ellentét kulturális mintázatként kezdett funkcionálni, a mintakövető pallérozódás így a korcsosulás veszélyét idézte fel.

A mintakövető pallérozódásnak mint kizárólagos értelmezési keretnek a megrendülése messzeható következményekkel járt a poézis státuszára nézve is, részben innen érthetö meg a Debreceni Grammatika által kezdeményezett vita a Magyar Museum programjával: „Köznép módjára, értelmesenn, és világosann adni-elő valamely derék dolgokat, nem egy könnyü; sőt sokkal nehezebb, mint tzifránn, tsürve-tsavarva, és sokaknak ítélete szerínt, felségesenn adni-elő [...] szükséges, hogy ollyan Könyveket vegyünk-elö fordítani, a mellyek nem tsak szókból és külömb-külömbféle haszontalan tzifrázatokból állanak; hanem hasznos dolgokkal tellyesek". ${ }^{102}$ Míg tehát a tudós hazafiak között folyt literátori vitákban az önelvű szépirodalom elemei kezdtek körvonalazódni az aestheticai vitapozícióhoz köthetően, a Debreceni Grammatika utólagos hozzászólása e vitákhoz éppen ezzel szemben foglalt állást, a poézis 'gyönyörködtetö' funkciója ellenében kijátszva a 'használni' követelményét.

A' tavasz eleje idézett záróbekezdése alapvetően a Debreceni Grammatika szellemében értett ellentétekre épül, ezért beszél távolságtartóan a 'pallérozódás úgynevezett barátairól', és ezért tesz hitet az 'elszilajult indulatok korcsosulástól mentes

\footnotetext{
${ }^{98}$ Minderről lásd Debreczeni, Tudós hazafiak, i. m., 217-240.

${ }^{99}$ Lásd erről Bíró, i. m., 372-375. Fazekas a 'kétfejű sas' szimbólumát két hírlapban megjelent katona-versében használta 1789-1790 során, majd még egyszer egy más természetü hasonlat részeként a Kalendáriomban, illetve ismeretes Kazinczy megjegyzése róla, mely szerint „nagy barátja a németnek”.

${ }^{100} \mathrm{~A}$ debreceniség mint tételezett identitás kérdéséről részletesen lásd DebreczeNI, $A$ debreceniség, i. $m$.

${ }^{101}$ Lásd Debreczeni, Tudós hazafiak, i. m., 240.

${ }^{102}$ Magyar Grammatika, i. m., XX-XXI.
} 
megszelidítése’ mellett. A záróbekezdést megelőző élőkép jellegű leírásban egy 'nyáját őgyelgető juhász' 'pásztori furulyáján' játszik, melyet a beszélö így kommentál: „Nem arra valók azok a goromba ujjak, hogy érzékeny dallokat játszanak a messzehangzó tárogatón". ${ }^{103} \mathrm{Az}$ 'érzékeny, nyájas, kicsinosodott' és a 'goromba, elszilajult' áll itt szembe a furulya és $A z$ én poézisomban is megidézett tárogató ${ }^{104}$ ellentétében, nemcsak poétai regiszterek gyanánt és korántsem egyértelmü minősítésben, mint azt az utolsó bekezdés megfogalmazza. Ha az e szövegben érzékelt kontextust lehetséges értelmezési kontextusnak tekintjük az életmü más szövegei esetében is, nevezetesen a hangszerkatalógust alkalmazó önértelmező szövegeknél, akkor a 'duda' és a 'doromb' olyan poétai használati módot jelöl, amelyet az 'úgynevezett pallérozódás' nem érintett. A szövegek ambivalenciája a két szempont együttes jelenlétére utal, amikor a 'felkentek' világával szemben magára mint 'kenetlenre' tekint: egyszerre van jelen az e használati móddal való megértő azonosulás és a távolságtartó önlekicsinylés szabadkozása, az extenuatio és a hypocrisis alakzata.

Nyilvánosság és szerzői név

A Kalendáriom magyarázatja után serkent gondolatok számvetésének referenciális megközelítésekor, a 'felkentek' Kazinczyra való konkrét utalása mögött, bizonyos szövegeket a Debreceni Grammatika felől olvasván szemléleti törésvonalat véltünk felfedezni. A 'kenetlen' kifejezést ennek során csupán a 'felkentek' ellentétpárjának tekintettük, de valójában az 'Én kenetlen' formula referenciális értelmezésének lehetősége és igénye éppoly logikusan vetődhet fel, mint a 'felkentek' esetében. A vizsgálathoz leginkább három levélrészlet szolgálhat kiindulópontként, nagyjából évtizedenként egy-egy, 1806-ból, 1815-ből és 1826-ból. Ezek által a 'kenetlen' mint önmeghatározás a szerzői névhasználat és a nyilvánosság viszonylatában válhat sajátosan értelemtelivé, visszatekintve a pálya egészének alakulására, s nem kizárólag a költői művekre vonatkozóan.

Kazinczyhoz írott, s önértelmező pozíciójának kettőssége kapcsán már idézett, 1806. szeptember 23-i levelének utolsó bekezdésében Fazekas mintegy mellékesen a következő megjegyzést teszi: „Én is írtam valaha verseket, de meg esmérvén az emberséges emberek Krisisseiből, hogy nem Poetának születtem, letettem rólla”. ${ }^{105}$ A szövegösszefüggés a kihagyásos megformáltság és a részben homályban hagyott

\footnotetext{
${ }^{103}$ FMÖM II. 13.

${ }^{104}$ A tárogató (azaz töröksíp) hadi és reprezentációs alkalmakkor használatos hangszer volt a 17-19. századi Magyarországon, Dugonics András Etelkájában Lehel kürtjével azonosítja, s a századvégen egyre inkább az ősi magyar hadi zeneszerszám kultikus funkciójába került irodalmi használata során. Minderről lásd Csörsz Rumen István, A törökök sípjától a magyar töröksípig = Identitás és kultúra a török hódoltság korában (16-17. század), szerk. Ács Pál, SzÉKely Júlia, Bp., Balassi, 2012, 338-358, föleg 345-347.

${ }^{105}$ KazLev. IV. 322., 997. sz.
} 
utalások miatt nehezen érthető. ${ }^{106}$ Most elegendő azt kiemelnünk, hogy a levél egészében mentesnek látszik a Fazekast egyébként olyannyira jellemző játékos kétértelmüségektől, ezért az idézett megfogalmazást biztonsággal vehetjük idézőjelek nélküli önértelmezésnek, teret engedve így a referenciális olvasatnak. Az „Én is írtam valaha verseket" kijelentés részben nem jelentett Kazinczynak új információt, ${ }^{107}$ részben nem is volt pontos, ha Fazekas bizonyosan 1805-1806-ból való verseire gondolunk. A 'valaha’ funkciója inkább a távolítás, amely a versírást a múlt részeként láttatja, korábban meghozott döntés következményeként: „nem Poetának születtem, letettem rólla”. E döntés ugyanakkor nem általában a versírásról való lemondást jelenti, hiszen ha jóval kisebb számban mint 1806-ig, ${ }^{108}$ de a későbbiekből is ismerünk verseket.

A szakirodalom gyakran idézte e mondatot különféle interpretációk kíséretében, hol komolyan véve azt, hol nem. Úgy véljük, e mondat legautentikusabban az Aprótseprőségek kéziratos gyüjteményének összefüggésében olvasható. Az Aprótseprőségek ugyanis, mint arról korábban részletesen szóltunk, az addigi poétai termést összegző gyüjteményes összeírás, amely a paratextusok tanúsága szerint a kiadás szándékával készült, időben minden valószínűség szerint 1806 előtt (1802-?1804), ami összhangban látszik lenni Fazekas későbbi levelének visszaemlékezésével. ${ }^{109}$ A gyüjtemény azonban nemcsak a poétaként való nyilvánosság elé lépés szándékát testesíti meg, de tanúsítja e szándék derékba törését is, hiszen a tisztázatnak indult összeírás a javítgatások által munkapéldánnyá vált, szerkezetében többszörösen átalakult, széttöredezett és végül megcsonkultan maradt ránk. Nem lehet filológiailag adatolni, miért tört derékba a versek kiadásának terve, de tény, hogy meghiúsult. A kiadás egyértelmű szándéka és a befejezetlenség ténye a Kazinczyhoz írott levél önértelmezését látszik hitelesíteni. A versek kiadása a

\footnotetext{
${ }^{106}$ A mondat így folytatódik: „és kritikussá lettem, mert ezt a mesterséget legkönnyebbnek leltem, kivált ha az ember indulatjait meg tudja elöször zabolázni”. Az egész megjegyzést Fabchich József Kazinczy lányának halálhírére megjelentetett verse kapcsán teszi, a kritikusra vonatkozó utalás jelentése nehezen felfejthető, referenciálisan legalábbis nem tudjuk értelmezni. S nem tudjuk azt sem, hogy kikre utal az emberséges emberek krizissei' korábbi megfogalmazása: Fazekas utóbb levelében Kazinczy Lúdas Matyi kapcsán tett 'jó tanácsairól és intéseiröl' szólt mindössze. A bekezdés egészében a szóban forgó mondatot olyan önképnek tekintjük, amelyet Fazekas részben a közölt verse alapján rossz poétának tartott Fabchich Józseffel, részben pedig az indulatait megzabolázni nem tudó kritikussal szegezett szembe. A kritikus itt leginkább megítélő olvasóként érthető, s lehet, hogy a megjegyzés éle Kazinczy ellen irányul, ő legalábbis levelei tanúsága szerint így érthette (KazLev. IV. 362., 1014. sz.). Ebben a szövegösszefüggésben az odavetett önértelmezés komolyan vehetö.

${ }^{107}$ Ö mutatta be úgy pár hónappal korábbi levelében Fazekast Cserey Farkasnak, mint 'Csokonai barátját, poetizáló és botanizáló társát' (KazLev. IV. 168., 928. sz.).

${ }^{108}$ A költői életmű időrendje, mint a bevezető fejezetben jeleztük, rendkívül bizonytalan, az azonban a bizonytalanságok figyelembevételével is valószínűsíthető, hogy a versek nagyobb része már készen volt e levél megszületése előtt, legalábbis a hiteles vagy feltehetően hiteles 99 szövegforrásból 14-ről állapítható meg, hogy későbbi, 24-et pedig egyáltalán nem tudunk keltezni.

${ }^{109}$ Fazekas 1815-ben úgy emlékszik vissza erre az egy évtizeddel korábbi időszakra, hogy „már akkor minden figyelmemet a fák, füvek, és virágok vonták magokra egész 1807-ig”, a Füvész Könyv megjelenéséig (FMÖM II. 97.).
} 
poétaként való színre lépés szimbolikus aktusa lett volna, ennek végleges elmaradása a poétai útról való lemondást jelentette. A „nem Poetának születtem, letettem rólla” olyan döntésröl nyilatkozik, amely a poétaként való önértelmezés elvetését jelenti. Verseket lehet még írni, de már poétai identitás nélkül, ha úgy tetszik, 'kenetlenként'.

Mikor Fazekas az 1804-ben készült, majd újradolgozott Lúdas Matyi Bécsbe küldését ígéri a kiadó Kerekes Ferencnek, az új kiadáshoz a következö feltételt is szabja 1815 novemberében: „A nevemről semmi emlékezetet benne ne tegyen, mivel nemzetünknek erántunk való érzéketlensége engem is azzá tett minden becsüllet eránt, melly a nyomtatás utján nyerődhetne. De az Úr engemet azért ne szánjon, mert hypocondriacus nem vagyok, hanem csak magyar." ${ }^{110}$ Nem tudjuk, hogy pontosan mit értsünk a 'magyar' megnevezésen, de nem is lényeges igazán. A fö közlés az, hogy Fazekas nem adja a nevét a mủ új kiadásához sem, aminek az oka egy korábbi sérelem. Az 'erántunk' visszautal a levél elejére, ahol a sógorával, Diószegi Sámuellel kiadott 'nagyreménységü' Füvész Könyvröl van szó, amelyben azonban 'megcsalattattak'. Mint 1823-as és 1825-ös jelentéseiből ${ }^{111}$ kiderül, a temérdek munkával és költséggel készült könyv példányainak többsége a nyakukon maradt, s noha helytartótanácsi dicséretet nyertek el érte, oktatási célra, amire szánták, nem került használatba. Ebből a csalódásból fakad, hogy a levélben Fazekas azt közli, lemondott a nyomtatott nyilvánosságban való bármely megjelenésről. S ezt nem csak hirdette, de eddig be is tartotta.

Az 1805-ben Kazinczy által publikált, Csokonait búcsúztató verse után csak az 1808-as új református énekeskönyvben jelent meg egy 1806 nyara előtt készült éneke, de névtelenül, majd ugyancsak névtelenül és tudta nélkül a Lúdas Matyi 1815-ben, melynek újrakiadásához neve elhagyásával járul hozzá e levélben. Az 1807-es Füvész Könyv után tehát csak az 1819-ben indított Kalendáriom tekinthető eredetileg is saját szándékból született publikációnak, ráadásul ennek szerkesztése 1828-as haláláig eltartott, s mint láttuk, Fazekas is sikeresnek tekintette, hiszen nagy példányszámával megvalósította kitűzött célját (ami a Füvész Könyvnek nem sikerült), vagyis hogy minél szélesebb körhöz eljutva hasznosuljon. Fazekas életművének három fő csomópontja (Aprótseprőségek, Füvész Könyv, Kalendáriom), úgy tűnik, nem elsősorban érdeklődésének sokirányúságáról vagy szórtságáról tanúskodik, hanem inkább a közhasznú cselekvés számára adekvát megnyilatkozási formájának kereséséről. A poétai útról való lemondás (az Aprótseprőségek befejezetlenül hagyása) párhuzamos volt az új terv, a Füvész Könyv kialakulásával és megvalósításával (vagy nem sokkal előzhette meg azt). A rákövetkező csalódás a nyilvánosság egészétől való elfordulást, sőt, a teljes visszavonultságot eredményezte egészen az új vállalkozás, a Kalendáriom megindításáig. Erre a bő évtizedre a Kalendáriom magyarázatja után serkent gondolatok is utalni látszik a haszon nélkül telt évek említésével, s a keserű tanulsággal: „Ha mikor nem kellettem, / Én arról nem tehettem."

\footnotetext{
${ }^{110}$ FMÖM II. 97-98.

${ }^{111}$ FMÖM II. 120-125.
} 
A Lúdas Matyi név nélkül való közlése iránti kérést a kiadó nem teljesítette (vagy csak Fazekas későbbi eltérő instrukciójának nem maradt nyoma), a címlapon és a szerzői előszó alatt F. M. monogram áll. A Kalendáriomban közölt verseket 1824-től szintén F. M. monogram jegyzi, miként néhány prózai szöveget is. Teljes neve egyszer sem szerepel az 1819-1828 között megjelent kötetekben, s a közlemények nagy része 1824 után is (miként előtte egészében) név nélkül jelent meg a Kalendáriomban. Fazekas Fodor Gerzsonnak írott, 1826. április 22-i levelében így magyarázza a monogram használatát: „A kalendáriumban talált ismertetés igaz, hogy az én munkám, de nem hiúságból bilyogoztam én azt meg, hanem irígységből, hogy másénak ne fogják, ami már ugyanazon kalendárium mottóival megtörtént." ${ }^{12}$ A kalendáriumok általános jellemzője a szerzői név mellőzése, ezért látja szükségesnek megindokolni, miért tért el saját addigi gyakorlatától is. A hiúság bủne helyett azért esett az irigység bűnébe, mert bizonyos szövegei mások általi saját célú felhasználását kívánta megakadályozni ezzel a köztes megoldással, amellyel valójában mégis folytatta addigi gyakorlatát. A szélesebb olvasóközönség előtt a monogram ugyanis csak megjelöli a szövegeket, anonimitásukat nem oldja fel, a szerkesztöt ismerő szűkebb (föleg debreceni) kör számára pedig ez ugyanúgy onimiaként érthetö, mintha a teljes nevet kiírta volna. ${ }^{113} \mathrm{~A}$ szerzői név tehát így is háttérben áll, nem tölt be integratív jelölő szerepet, hanem a kiadvány funkciójának rendelődik alá. Miként valójában mindig Fazekas esetében.

Teljes nevével mindössze öt műve jelent meg, a Füvész Könyv és négy vers, ez utóbbiak azonban nem a saját kiadásában. Katonáskodása idején, hírlapokban közzétett versei mellett kétszer ${ }^{114}$ szerepel a neve (1789-1790), de csak szerkesztöi jegyzetben, s első közleményét bizonyosan nem maga küldte be a laphoz. A szintén teljes névvel jegyzett, Csokonai halálára szóló költeményt Kazinczy adta ki 1805-ben, miként utóbb a Nyári esti dalt is 1825-ben. Nem ismerünk tehát olyan publikált verses alkotását, amely teljes nevével, saját kiadásában jelent meg, prózait is csak egyet. Költeményei kézirataiban pedig mindössze kétszer áll teljes neve szerzői névként, legnagyobb gyüjteménye, az Aprótseprőségek név nélküli, monogram sehol nem szerepel. Négy verses levele közül a Csokonainak címzett kettőben (1802) az aláirás maga is játékká válik, ${ }^{115}$ így csak a Kazinczyhoz szóló kettőben (1805) használja azt egyben szerzői névként. Mindkét alkalommal a 'Fő Hadnagy' titulust illeszti hozzá, miként majd a Füvész Könyvben is (1807),

\footnotetext{
${ }^{112}$ FMÖM II. 110.

${ }^{113}$ Ugyancsak monogrammal jegyezte Kazinczy ellen írott hírlapi cikkét („A megrágalmazott városnak egy fia F. M., FMÖM II. 26.). Az anonimia és onimia fogalmait Onder Csaba használja, Genette után: ONDER, i. m., 94-99.

${ }^{114}$ A másik két alkalommal egy „Magyar Huszár-Tisztünk”-et nevezte meg a szerkesztő a versek fordítójaként, ami nagy valószínűséggel, de nem bizonyíthatóan Fazekasra utal.

${ }^{115} \mathrm{Az}$ egyikben szándékosan olvashatatlan az aláírás, összhangban az utóirat és a címzés tréfálkozó jellegével (Csokonai Vitéz Mihály Összes Müvei, Levelezés, kiad. Debreczeni Attila, Bp., Akadémiai, 1999, 678.), a másikban Csokonai nevére rímeltetve játszik rejtőzködést. Erről lásd SzILÁGYı Márton, A költő mint társadalmi jelenség, Bp., Ráció, 2014, 110.
} 
s a négy teljes névvel közölt versnél ugyancsak mindig ezt írta a név alá a közlö. ${ }^{116} \mathrm{E}$ titulussal emlegette Fazekast leveleiben, naplóiban Kazinczy, s Csereynek 'pensionatus' (azaz nyugdíjas) 'föhadnagyként' mutatta be, aki mintegy mellesleg 'poetizál és botanizál. Az önerőből elért katonai rang használata a szerzői név mellett így konstans önmeghatározás, és egyben a társadalmi pozíció elfogadott jele.

A kor szerzői névhasználatában a leggyakoribb éppen az onimia volt, mikor is a polgári név mellett sokszor szerepeltettek a társadalmi státuszra utaló megnevezést. Fazekas esetében tehát nem ez a szerzői névhasználat és az abban megtestesülő önmeghatározás a feltünő, hanem ennek a ritkasága. Mondhatni csupán a Füvész Könyv esetében érzékelhetö a mü szerzői névhez való kötésének explicit szándéka Fazekas részéröl, minden más esetben vagy nem ő teszi ezt meg, vagy a müfaj, illetve a kiadványtípus jellemzői befolyásolják. E könyv pedig csalódást eredményez, ami a poétaságról való lemondás után a tudósi önmeghatározás elvetését is jelenti. Az 'úgynevezett pallérozottak' által szabályozott nyilvánosságban érvényes két alapvető szerepfelfogástól való elfordulás egyben a jelölő funkcióval rendelkező szerzői név végleges háttérbe szorulását eredményezi. E helyzet adekvát kiadványtípusa a kalendárium, amely tökéletes eszközt jelent Fazekasnak a közvetlen és széles körben ható hasznosságról vallott felfogása megvalósításához. E kiadványtípus csekély presztízzsel rendelkezik a 'felkentek' által uralt nyilvánosságban, de ez benne csak a 'kenetlenek' korábban is meglévő önérzetét erösíti öntudattá.

Az 'Én kenetlen' mint önértelmezés mindezek alapján nem „vállalt outsiderségnek" tekinthetö, amint Bécsy Ágnes Fazekas pályája egészére nézve megállapítja, még akkor sem, ha hozzáteszi, hogy ez „nem könnyed dilettantizmussal párosult, hanem diszciplinált, profi érdeklődéssel”. ${ }^{117}$ A dilettáns-professzionális fogalompár mint megközelítésmód némiképp maga is félrevezetö, hiszen mai jelentésárnyalatokat vetít viszsza Fazekas korába, melyek akkor nem vagy nem így léteztek. Akkoriban a kennerliebhaber, a connaisseur-amateur, vagy Kazinczynál az artista-dilettant fogalompár volt használatos, mindkét elemében elfogadó módon. ${ }^{118}$ Fazekas önmeghatározása látszólag inkább az alkalmi költő pozíciójával tünik hasonlatosnak, aki ugyanúgy a szerénység-toposzt alkalmazva, az ízlések különbözőségének elvére hivatkozva és a külső kritikát valójában elutasítva szól 'tehetségének hajszálnyi vékonyságáról', az ő 'Parnasszusának alacsony voltáról' és műveit 'Semminél több valaminek' nevezi. ${ }^{119}$ A felkentek által lenézett alkalmi költő azonban ugyanúgy a Helikonra tör, mint a

\footnotetext{
${ }^{116}$ A hírlapi közlés idején még hadnagy volt, az egyik helyen ez áll, a másik helyen tévedésből alhadnagy. ${ }^{117}$ BÉCsY, Egy jó költö, i. m., 10. Az alkotói tevékenység „professzionalizmusára” számos bizonyíték mellett megemlíthetjük eddig kevéssé számon tartott korrekciós tevékenységét, amely jól szemlélhető az Aprótseprőségek átdolgozásaiban, a Kalendáriom most előkerült korrektúrapéldányán, a Lúdas Matyi 'körbenyalogatásán' és a Fodorhoz írott levél megjegyzésén: „a betűszedés napjáig mindig fogok rajta fúrni-faragnivalót találni” (FMÖM II. 110.).

${ }^{118}$ E kérdéskör rövid összefoglalása, a szakirodalmi háttér megadásával: DeBRECZENI, Tudós hazafiak, i. m., 419-422.

${ }^{119}$ Az idézetek Gyöngyössi Jánostól és Mátyási Józseftől származnak.
} 
felkentek, s éppen hogy nem óhajt kívül állni, míg Fazekas nem törekszik a Helikonra, így ő nem a felkentek körén kívül áll, hanem hozzájuk képest máshol, s legfeljebb csak a 'felkentek', 'pallérozottak' nézőpontját elfogadva nevezhető kívülállónak.

Fazekas más terepet és más célokat jelöl ki a maga számára, s ehhez keresi az adekvát szerepet és megnyilvánulási lehetőséget. A nyilvánossághoz való viszony szempontjából ez sajátosan ellentmondásos helyzetet jelent, mert egyrészről mindvégig törekszik a nyomtatott nyilvánosság használatára, másrészről viszont önértelmezése folytonos távolodásban van az e nyilvánosságban elfogadottnak tekintett szerepfelfogásoktól, $\mathrm{s}$ leginkább egy szűkkörü, közösségi típusú nyilvánosságban tűnik autentikusnak. Az ő igazi közege az 1770-es évek társulatainak mintájára gondolható el, amikor a közösségi létmód részben kiegészítette, részben helyettesítette a nyilvánosság még alig létező fórumait. Csakhogy míg akkor az integrációs tendenciák voltak meghatározóak, ebben az esetben, Fazekas időben változó összetételü, de folyamatosan aktívnak tünő debreceni társulatában inkább az elkülönülés mozzanatai a jelentősek.

Ez az elkülönülő társulati-közösségi nyilvánosságforma a korszak általánosan használatos beszédmódjainak összefüggésében szemlélve sajátos ideologikus pozícióhoz kapcsolódik. A Debreceni Grammatika szemlélete mind a művelődés, mind az identifikáció kontextusában kilép a mintakövetés közmegegyezéses modelljéböl, s a modernizáció organikus útjának pozíciója felé mozdul el. A tudomány-és poézisfelfogás összefüggésében ez a szemlélet a horatiusi használni és gyönyörködtetni elv kettősségén belül az előbbire helyezi a hangsúlyt. Tudomány és poézis egysége valójában a fiziko-teológia szemléletmódjában alapozódik meg, amelynek a debreceni kollégium volt a meghatározó közege, $s$ amely a 18. század utolsó harmadában és a századfordulón kiterjedt és széles körben ható irodalmat hozott létre. ${ }^{120}$ Fazekas Mihályt e hagyomány legnagyobb költőjének tarthatjuk, életművének a kor fő vonulataitól való eltéréseit nem kis mértékben erre vezethetjük vissza. Továbbá arra a saját pozícióját folytonosan megkettőző, ironikusan játékos költői szemlélet- és alkotásmódra, amely valójában a fiziko-teologizmustól is oly idegen. Az 'Én kenetlen' önértelmezése plasztikusan nyilvánítja meg mindezt a Kalendáriom magyarázatja után serkent gondolatok pálya végi számvetésében, immár identifikációs energiával ruházva fel korábbi önértelmezései eredendően ambivalens önérzetét.

\section{'Mégis, kinek a kortársa?'}

Horváth János Fazekasról írott pályaképe 1936-os Csokonai-kismonográfiájában kapott helyet, melynek alcíme Csokonai költö-barátai: Földi és Fazekas. Jelentős

\footnotetext{
${ }^{120}$ Szauder József és Imre Mihály már említett nyomatékos jelzései nyomán valóban indokoltnak látszik a debreceni kollégium szellemi közegéhez köthető századvégi-századfordulós fiziko-teologiai hagyomány monografikus feldolgozása.
} 
előzmények után, máig ható erővel sorolta be Fazekas életművét Csokonai árnyékába, s még az egyenjogúsításáért mindent megtévő Julow Viktor is alapvetően fogságában maradt. Bécsy Ágnes volt, aki kimondta: „Csokonai egyeduralmát adott esetben indokolt volna - legalább hipotetikusan - mérsékelni és számításba venni azt a lehetőséget, hogy Fazekas lírája más korabeli életmüvekhez is hozzámérhetöo" Majd javaslatot is tett egy új bemérési pontra: „kockáztassuk meg azt a hipotézist, hogy Fazekas [...] par excellence neoklasszicista érzékenységével, poétikailag legsikeresebb és legrelevánsabb megoldásaiban nem Csokonai, hanem már Berzsenyi kortársa volt". ${ }^{121}$ A jelen dolgozat pedig, ugyancsak hipotetikus érvénnyel, Szőnyi Benjámint hozta szóba Fazekas életmüvének kontextusaként. Szőnyi-Csokonai-Berzsenyi. Joggal tehető fel a kérdés: akkor kinek is a kortársa Fazekas?

Bécsy Ágnes felvetése megfogalmazásában hordozza fejlődéstörténeti érdekeltségét („már Berzsenyi kortársa volt”). A 'kortárs' persze érthető a Bécsy Ágnestől vett idézet első felében olvasható értelemben is („más korabeli életművekhez is hozzámérhető”). Ha az egy időben élt alkotók párhuzamosan formálódott életműveinek egymáshoz méréséről van szó, akkor a három szóba hozott alkotó egyaránt releváns Fazekas szempontjából, hiszen Szőnyi Benjámin utolsó művét akkortájt publikálta, mikor Fazekasnak elöször jelentek meg versei hírlapokban, Csokonaival való közös debreceni éveik közismertek, ahogy müveik kapcsolatai is a Fazekas-szakirodalom fontos témái voltak, Berzsenyivel pedig a leghosszabb ideig futott párhuzamosan pályájuk. Ha viszont fejlődéstörténeti időgörbék szerint tekintünk ezen életművek párhuzamosságára, akkor leginkább az egyidejü egyidejütlenség szemlélhető általuk. Nehéz a választás, sőt, nem is lehetséges ebben az általánosságban. Végezzük inkább elemekre bontva az összemérést, a szemléletmód, a poézisfelfogás, a költészeti hagyományok és a költői teljesítmény szempontjaiból.

Fazekas életmüvét elemzéseink szerint alapvetően a fiziko-teológiai szemléletmód látszik meghatározni, tudományfelfogásában éppúgy, mint providenciális karakterében és morálteológiai implikációiban. Ezt láthattuk feltünni a Kalendáriom és a Füvész Könyv hátterében, a Lúdas Matyi példázatában, valamint a versek világában, tematikusan és leíró technikában egyaránt. Szőnyi, Csokonai és Berzsenyi esetében egyaránt releváns kontextus a fiziko-teológia, míg azonban Szőnyi esetében minden belső meghasonlás ellenére sem veszít érvényéből, Csokonai életművében egyértelműen meghaladott szemléletmódnak tekinthető, Berzsenyinél pedig sajátos neoplatonista átértelmeződésen megy keresztül. Fazekas számára, mint az éppen Csokonaival összevetve látszik világosan, a fiziko-teológiai szemléletben adott, gondviselés elvü morális világkép mindvégig általános és szilárd értelmezési keretet jelent. ${ }^{122} \mathrm{E}$ végső kétely nélküli, átértelmezéseknek nyomát sem mutató szemlélet leginkább Szőnyi Benjámin és a 18. század utolsó harmadának kiterjedt átlag fiziko-teológiai irodalma felől látszik bemérhetőnek.

\footnotetext{
${ }^{121}$ BÉcsY, Egy jó költö, i. m., 11, 12.

${ }^{122}$ Bíró Ferenc úgy fogalmaz, hogy Fazekas megmarad „a vallás hagyományos és megszokott körletében”. Bíró, i. m., 379.
} 
Fazekas poézisfelfogásáról kevés az autentikus forrás, s ez önmagában jelentéses. A poézist a horatiusi használni és gyönyörködtetni elve alapján, a horatiusi elvet pedig a Szent Dávid-i értelemben vett 'példázat' modellje szerint érti, vagyis önmagán (és gyönyörködtető funkcióján) túlmutató 'alkalmazott költészetként', amely végső soron az isteni szó és az erkölcs megnyilvánítója kell legyen. E poézismodell példázatos jellege ugyanakkor az exemplum-hagyománynak megfelelően szabad teret enged a példázat megjelenítésének, ahogy azt a Lúdas Matyi fabuláris szintjén az önmagában megálló, $s$ lényegében a példázaton túlnövő mesei történetben látjuk, vagy a költemények tematikájának profán területein, a gyönyörködtető funkció spontán felerösödésében. E szempontból megint csak Szőnyi Benjámin kínálkozik analógiaként Fazekas archaikusabb költészetfelfogásához, hiszen Csokonai és Berzsenyi számára, miként a 18. század végének legtöbb írójánál, a poézis már tényleges és kimondott önértékkel bír, természetesen az utile et dulce keretein belül.

Fazekas költői életművének hagyományrendje leginkább Berzsenyiéhez hasonlatos, amennyiben az énekköltői hagyomány és az antik időmértékes formakultúra határozza meg. Csokonaihoz képest ez kétségtelenül szűkebb territórium, Szőnyi Benjáminhoz képest pedig tágabb és más. E vershagyományok, melyek az 1770-es évekre alakultak ki, a későbbi költészeti formakincs alaprétegét képezik. Fazekas következetes ragaszkodása ezekhez költészetének (minden látszólagos sokarcúsága ellenére is) egységes és zárt jelleget kölcsönöz, melyet nem érintenek meg a századvégen jelentkező programosan újító költészeti irányok. Költői életművét autentikusan értelmezni és a költői teljesítményt megítélni leginkább e hagyományok alapján lehet, noha például SzegedyMaszák Mihály megállapítja, hogy a „globális szerkesztést tekintve kétségkívül ő volt korának legtöbbet kezdeményező költője”. ${ }^{123}$ Az újítás önmagában nem lehet szinonimája a teljesítménynek, ${ }^{124}$ egy újítás előtti vagy korlátozottan újító életmü éppúgy lehet minőségében jelentős, mint egy újító csekély értékű. Fazekas költészete alapvetően a hagyományban gyökerezik, abban, azáltal alkot jelentőset, amely biztosítja kitüntetett helyét az irodalomtörténeti kánonban.

A Fazekas életmű egyediségét ${ }^{125}$ ugyanakkor éppen a hagyományoktól való merész eltérés jelenti, amely azonban nem tekinthető a poétikai újítás tudatos törekvésének. Ez leginkább az irónia és játékosság átható jelenlétében érhető tetten, ami termékeny feszültségben áll a hagyományban gyökerező szemléletmód méltóságával és stabilitásával. Visszatérő eleme verseinek a makro- és mikrokozmosz összevillantása, mikor a végtelen terek látványa által keltett fenséges érzületet az álomból felébredés profán effektusai ellenpontozzák, vagy fenséges és humilis hangnemeinek ütköztetése, keverése, gyakran különféle intertextuális játékok által, barátaival évődve. Különösen fontos az önértelmezés sajátos kettőssége, a külső és belső nézőpont egymásra vetítése, s az így

\footnotetext{
${ }^{123}$ SZegedy-Maszák, i. m., 70.

${ }^{124}$ Lásd erről IMre, Vesztett csata, i. m., 167.

${ }^{125}$ Fazekas egyediségének kérdését $\mathrm{S}$. Varga Pál megjegyzései vetették fel inspirálóan.
} 
kiváltott elbizonytalanító hatás, az egyértelműség idézőjelbe tétele. Az irónia kiváltképp modernnek érezhető a romantikus irónia fénytörésében, de esetében ez sokkal inkább alkati sajátosságnak tünik, ami a fiziko-teológia által adott szemléleti kereteket nem kezdi ki, noha nyilvánvaló ellentétben áll azokkal.

Mégis, kinek a kortársa volt hát Fazekas Mihály? Ha Bécsy Ágnes úttörő jellegű felvetését tekintjük, amely általában Berzsenyivel és a neoklasszicizmussal kapcsolja össze életművét több valóban releváns jellegzetesség alapján, akkor azt mondhatjuk, hogy legfeljebb schilleri értelemben tudjuk elképzelni párba állításukat. Úgy, ahogyan A naiv és szentimentális költészetről szóló híres tanulmányban Schiller magát Goethével állította szembe, mint az elégikus és az idilli, azaz a szentimentális és a naiv költészet képviselőit. Fazekas ebben a beállításban a naiv megtestesítője lehet, mert semmi jele életművében az eszményítő reflexivitásnak, ami Berzsenyi költészetének kitüntetett sajátossága. De talán sokkal jobb úton járunk, ha nem egészében kívánjuk minősíteni az életművet, nem az egészhez keresünk bemérési pontokat mondjuk Szőnyi, Csokonai és Berzsenyi munkásságában, hanem inkább abban a bontásban, amelyet a jelen öszszefoglalásban alkalmaztunk (szemléletmód, poézisfelfogás, költészeti hagyományok, költői teljesítmény). Innen nézve elég differenciált kép bontakozhat ki előttünk: Fazekas életművében maga az egyidejü egyidejütlenség látszik megtestesülni.

\begin{tabular}{c}
\hline Debreczeni Attila \\
egyetemi tanár \\
Debreceni Egyetem \\
debreczeni.attila@arts.unideb.hu
\end{tabular}

Starting Points and Contexts for the Reinterpretation of the Oeuvre of Mihály Fazekas

\begin{abstract}
The first part of the study gives a summary of the textological approach to the oeuvre of Mihály Fazekas, detailed elsewhere. This is followed by the highlighting of four contexts grouped around the concepts of Poetry, Morals, Sciences and Interpretation of self, all of which focus on a text source or group of text sources. The connection between the chapters is built retroactively, later chapters and the points discussed therein refer back to relevant concepts in previous ones. After the description of the possible contexts, the last chapter discusses the different aspects for the evaluation of the whole oeuvre, and gives a number of hypotheses, hoping to inspire further research.
\end{abstract}

Keywords: Mihály Fazekas, literary history, poetry, almanac, physico-theology

DOI: $10.37415 /$ studia/2020/3-4/12-55.

Open Access: Creative Commons Attribution 4.0 International (CC BY 4.0) 